\title{
Photophysical, Electrochemical and Photovoltaic Properties of Porphyrin-Based Dye Sensitized Solar Cell
}

\author{
William Ghann', Tulio Chavez-Gil2 ${ }^{2}$, Carentxa I. Goede ${ }^{2}$, Hyeonggon Kang ${ }^{1}$, Shamsuddin Khan', \\ Hany Sobhi', Fred Nesbitt ${ }^{1}$, Jamal Uddin ${ }^{1 *}$
}

${ }^{1}$ Center for Nanotechnology, Department of Natural Sciences, Coppin State University, Baltimore, MD, USA

${ }^{2}$ Inorganic Synthesis Lab, Department of Natural Sciences, Coppin State University, Baltimore, MD, USA

Email: *juddin@coppin.edu, *tchavez-gil@coppin.edu

How to cite this paper: Ghann, W., Chavez-Gil, T., Goede, C.I., Kang, H., Khan, S., Sobhi, H., Nesbitt, F. and Uddin, J. (2017) Photophysical, Electrochemical and Photovoltaic Properties of Porphyrin-Based Dye Sensitized Solar Cell. Advances in Materials Physics and Chemistry, 7, 148-172. https://doi.org/10.4236/ampc.2017.75013

Received: March 23, 2017

Accepted: May 14, 2017

Published: May 17, 2017

Copyright $\odot 2017$ by authors and Scientific Research Publishing Inc. This work is licensed under the Creative Commons Attribution International License (CC BY 4.0).

http://creativecommons.org/licenses/by/4.0/

\section{cc) (i) Open Access}

\begin{abstract}
Porphyrins occur in a number of important biomolecules and are also synthetically made for use as probe component of chemical and biological sensors. The performance of dye sensitized solar cells with two different porphyrin dyes was investigated in this work. The two porphyrin complexes comprised of a metal-free 5, 10,15, 20-meso-tetrakis-(9H-2-fluorene-yl) porphyrin $\left(\mathrm{H}_{2} \mathrm{TFP}\right)$ and its Zinc complex (ZnTFP). UV-Vis, Fluorescence, and Fourier transformed infrared measurements of the two dyes were carried out to evaluate their absorption, emission and binding characteristics. Both dyes absorbed light in the UV-visible region all the way to the near-infrared. The surface morphology and elemental analysis of the porphyrin dye sensitized photoanodes were determined using Field Emission Scanning Electron Microscopy Imaging and Transmission Electron Microscopy Imaging. Cyclic voltammetry studies, current-voltage characteristics and the electrochemical impedance spectroscopic studies were also carried out. Solar-to-electric energy efficiency of $\mathrm{H}_{2}$ TFP dye sensitized solar cell was higher (0.11\%) than that of the zinc complex $(0.08 \%)$. Thus the metal free porphyrin generated more power than the zinc complex under similar conditions. The impedance measurement also displayed less overall resistance for the free porphyrin $(50 \Omega)$ compared with the zinc complex $\left(130 \Omega\right.$ ). The LUMO levels of $\mathrm{H}_{2}$ TFP and ZnTFP sensitizers were $-0.87 \mathrm{eV}$ and $-0.77 \mathrm{eV}$ respectively. Both of these LUMO values are higher than the lower bound level of the conduction band of $\mathrm{TiO}_{2}(-4.0 \mathrm{eV})$, ensuring the efficient injection of an electron from the excited porphyrin dye to the conduction band of the titanium dioxide.
\end{abstract}

\section{Keywords}

Porphyrin Dyes, UV-VIS, Fluorescence, Lifetime Decay, IR, FESEM, TEM, I-V, Cyclic Voltammetry, Impedance and DFT Calculation 


\section{Introduction}

Dye sensitized solar cells (DSSCs) use dyes to absorb energy from the sunlight to produce excited electrons for the generation of electricity [1] [2] [3] [4] [5]. They are inexpensive, easy to produce and environmentally friendly. DSSCs are composed of a working electrode, usually a dye sensitized nanocrystalline $\mathrm{TiO}_{2}$ on a conductive glass slide, a counter electrode, typically made of carbon or platinum on a conductive glass slide, and an electrolyte-a redox couple placed between the two electrodes for the regeneration of charge. Upon absorption of incident light, dye molecules are excited and subsequently relax by the injection electron into the conduction band of the $\mathrm{TiO}_{2}$ semiconductor. Both natural pigments [6]-[12] and synthetic dyes [13] [14] [15] [16] have been used as photosensitizers for DSSCs. Here, two different porphyrins dyes have been used as photosensitizers for DSSC. Porphyrins are heterocyclic macrocycle organic compounds that usually bind with metals such as Magnesium and Ruthenium to form complexes. An example of naturally occurring porphyrins is the pigment, heme, found in red blood cells. It is also the basic structure of chlorophyll, the green pigment found in green plants. The large conjugation system of porphyrins allows for intense absorption in the visible region of the electromagnetic spectrum which makes them great candidates for use as photosensitizers in the construction of dye sensitized solar cell. Indeed, a number of studies on DSSCs with different types of porphyrins as photosensitizers have been reported [17]-[26].

In this work, a free base 5, 10, 15, 20-meso-tetrakis-(9H-2-fluorene-yl) porphyrin $\left(\mathrm{H}_{2} \mathrm{TFP}\right)$ and its Zinc complex (Zn-TFP) have been synthesized and characterized to study the photo-physical and current-voltage properties of the DSSC.

\section{Experimental Section}

\subsection{Materials and Methods}

Reagents were purchased commercially and used as received, except for pyrrole and DMF that were redistilled by literature procedures [27]. All synthesis and air-sensitive characterization processes were carried out under a vacuum line and standard Schlenk techniques. Solvents for synthesis and spectroscopic characterization (ACS Grade) including dichloromethane (DCM), chloroform, hexanes, alcohols, and tetrahydrofuran were either purchased from Sigma-Aldrich, St. Louis, MO, or Across Organics, NJ, USA. Doubly purified deionized water from an $18 \mathrm{M}$ Millipore system was used for aqueous solutions. N, N'-dimethylformamide (DMF) was distilled over calcium hydride under $\mathrm{N}_{2}$ flow. $\mathrm{Zn}(\mathrm{OAc})_{2} \cdot 2 \mathrm{H}_{2} \mathrm{O}$ was synthesized with high purity and checked through NMR spectrometry and melting point techniques. Column chromatography was carried out using silica gel 60, 230 - 400 mesh, from EMD Chemicals. The proton NMR spectrum was collected on a Bruker Avance III $400 \mathrm{MHz}$ NMR spectrometer; FT-IR spectra were collected as $\mathrm{KBr}$ disk on a Nicolet iS50 FT-IR spectrometer; Electrochemistry determinations were collected in DMF solutions on a Princeton Applied Research VersaSTAT-3 potentiostate using a three electrode 
cell unit. Steady-state absorbance spectra were measured on a Perkin Elmer Lambda 850 UV-visible (UV-vis) spectrophotometer and spectra were collected in DCM or chloroform solution. Elemental analyses were obtained from Galbraith laboratories Inc (Knoxville, TN). Titanium dioxide powder (Degussa P25) was purchased from the institute of chemical education. Fluorine tin oxide (FTO) conducting glass slides were purchased from Harford glass company, Hartford City, Indiana.

Steady-state fluorescence spectra were recorded on the fluorescence Nanolog Spectrofluorometer System from Horiba Scientific (FL3-22 iHR, Nanolog). The morphology of each film was analyzed using field emission scanning electron microscopy (FESEM; JSM-7100FA JEOL USA, Inc.). Transmission Electron Microscopy (TEM) images were acquired on JEM-1400 Plus (JEOL USA, Peabody, Massachusetts). The images were viewed using Digital Micrograph software from Gatan (Gatan. Inc, Pleasanton, CA). HOMO and LUMO calculations were carried out using Spartan'14 software from Wave function, Inc. Irvine, CA, and USA. $\mathrm{TiO}_{2}$ paste was printed on FTO glass using WS-650 Series Spin Processor from Laurell Technologies Corporation.

\subsection{Synthesis of 5, 10, 15, 20-Meso-Tetrakis-(9H-2-Fluorene-yl) Porphyrin}

The synthesis of 5,10,15, 20-meso-tetrakis-(9H-2-fluorene-yl) porphyrin, denoted as $\mathrm{H}_{2}$ TFP, was carried out by the synthetic route shown in Scheme 1. In a $400 \mathrm{~mL}$ three-neck round-bottom flask equipped with a magnetic stirring bar and surmounted by a reflux condenser, freshly distilled pyrrole (1.45 g, 21.6 $\mathrm{mmol}$ ), was added to a solution of fluorene-2-carboxaldehyde (4.2 g, 21.6 $\mathrm{mmol})$, and propionic acid $(180 \mathrm{~mL})$ previously degassed through $\mathrm{N}_{2}$. After reagents were mixed, the system was immersed in an oil bath and temperature was raised to $130^{\circ} \mathrm{C}$. The reaction mixture was refluxed for $6 \mathrm{~h}$ to complete the reaction. The reaction progress was monitored by taking aliquots of the solution and recording its UV-vis spectra. After a constant pattern was observed for the Soret $(=424 \mathrm{~nm})$ and $\mathrm{Q}$ bands, the reaction was stopped, allowed to reach room

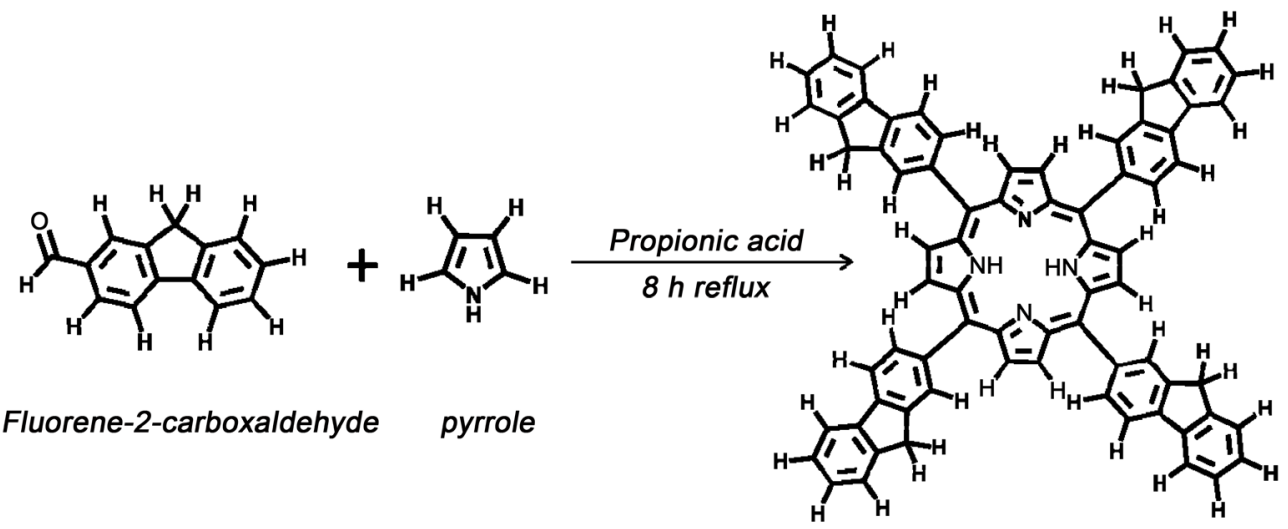

5, 10, 15, 20-meso-tetrakis-2-(9H-fluorene-yl)porphyrin

Scheme 1. Synthesis of $\mathrm{H}_{2}$ TFP freebase. 
temperature and crunched ice added to precipitate a deep green-violet solid. The cold solution was filtered and the residue washed several times with methanol until no more colored solution was observed in the filtrate. The resulting tarry residue was triturated with toluene $(50 \mathrm{ml})$ and allowed to stand in the refrigerator overnight. A fine purple powder was precipitated, filtered and washed thoroughly with cold toluene. The dried powder was dissolved in dichloromethane $(100 \mathrm{ml})$, treated with trifluoroacetic acid $(0.15 \mathrm{ml})$, and allowed to stir at room temperature for $4 \mathrm{~h}$. The reaction mixture was refluxed for an additional $2.5 \mathrm{~h}$ and allowed to cool down to room temperature after which, a saturated solution of sodium carbonate, $\mathrm{NaHCO}_{3}(100 \mathrm{~mL})$ was added and the mixture was washed with water $(2 \times 100 \mathrm{~mL})$ to attain an organic face after separation. Methanol $(100 \mathrm{~mL})$ was added over the organic layer to precipitate the free base $\mathrm{H}_{2}$ TFP that was collected by filtration, washed several times with cold methanol and dried in desiccator under $\mathrm{CaCl}_{2}$. The solid was dissolved in a little amount of dichloromethane $(\sim 7 \mathrm{~mL})$ followed by purification on an alumina column. Eluting with pure dichloromethane then ensued affording a pure compound that was also characterized by UV-Vis giving a sharp Soret band at $424 \mathrm{~nm}$. The solvent was evaporated on rotavapor system and the solid was re-dissolved once more in dichloromethane and filtered over cotton to remove any impurities. The filtrate was recovered in a vial and kept in a dark place at room temperature for several days under gentle evaporation, yielding a deep green-foiled material. Yield, $1.06 \mathrm{~g}$ (25.2\%). Anal. Calcd for $\mathrm{C}_{72} \mathrm{H}_{46} \mathrm{~N}_{4} \cdot \mathrm{CH}_{2} \mathrm{Cl}_{2}, \mathrm{H}_{2}$ TFP (MW = 967.22 g/mol): C, 83.32; H, 4.60; N, 5.32. Found: C, 83.31; H, 4.30; N, 5.61. Figure 1 shows the NMR spectrum of $\mathrm{H}_{2}$ TFP. ${ }^{1} \mathrm{H}-\mathrm{NMR}\left(400 \mathrm{MHz}, \delta \mathrm{ppm}\left(\mathrm{CDCl}_{3}\right): 8.94\right.$ $\left(\mathrm{s}, 8 \mathrm{H}, \mathrm{CH}_{\beta \text {-pyrrolic }}\right), 8.42\left(\mathrm{~s}, 4 \mathrm{H}, \mathrm{H}_{\text {fluorenyl }} \mathrm{H}_{1}\right), 8.28\left(\mathrm{~d}, 4 \mathrm{H}, J_{\mathrm{HH}}=0.1 \mathrm{~Hz}, \mathrm{H}_{\text {fluorenyl }}\right.$, $\left.\mathrm{H}_{4}\right), 8.17\left(\mathrm{~d}, 4 \mathrm{H}, J_{\mathrm{HH}} 0.02 \mathrm{~Hz}, \mathrm{H}_{\text {fluorenyl }}, \mathrm{H}_{3}\right), 8.07\left(\mathrm{~d}, 4 \mathrm{H}, J_{\mathrm{HH}}=0.02 \mathrm{~Hz}, \mathrm{H}_{\text {fluorenyl }}\right.$, $\left.\mathrm{H}_{5}\right), 7.72\left(\mathrm{~d}, 4 \mathrm{H}, J_{\mathrm{HH}}=0.2 \mathrm{~Hz}, \mathrm{H}_{\text {fluorenyl }}, \mathrm{H}_{8}\right), 7.55\left(\mathrm{t}, 4 \mathrm{H}, \mathrm{H}_{\text {fluorenyl }}, \mathrm{H}_{6}\right), 7.46(\mathrm{t}, 4 \mathrm{H}$, $\mathrm{H}_{\text {fluoreneyl }}, \mathrm{H}_{7}$ ), 7.24 (strong $1 \mathrm{H}, \mathrm{CDCl}_{3}$ ), 5.43 (s, 2H, dichloromethane-trace), 4.22 (s, $8 \mathrm{H}, 4 \mathrm{CH}_{2 \text {-fluorenyl }}$ ), and -1.36 (s $2 \mathrm{H}, \mathrm{H}_{\alpha \text {-pyrrolic }}$, not shown). FT-IR (KBr disk, $v / \mathrm{cm}^{-1}$ ): $3438 \mathrm{~m}, 3044 \mathrm{~m}, 2894 \mathrm{w}, 1706 \mathrm{~s}, 1553 \mathrm{~m}, 1456 \mathrm{~m}, 1401 \mathrm{w}, 1298 \mathrm{br}$, UV-vis (CH2Cl2) 413, 507, 536, 583, 637 nm. 1226 w, 1049 w, 1004 w, 972 w, $800 \mathrm{w}, 765 \mathrm{~m}, 734 \mathrm{~s}, 422 \mathrm{w}$. UV-vis $\operatorname{DCM}(\lambda, \mathrm{nm}),\left(\varepsilon, 10^{5} \mathrm{M}^{-1}, \mathrm{~cm}^{-1}\right): 424$ (Soret), $518,554,591,649$ (Qs).

\subsection{Complex Zn-5, 10, 15, 20-Meso-Tetrakis-(9H-2-Fluorene-yl)Porphyrinato(II)}

$\mathrm{Zn-5}, 10,15,20$-meso-tetrakis-(9H-2-fluorene-yl) porphyrinato (II), denoted as $\mathrm{ZnTFP}$, was prepared according to the synthetic route shown in Scheme 2. In a $50 \mathrm{~mL}$ two-neck round-bottom flask, $50 \mathrm{mg}(0.22 \mathrm{mmol})$ of $\mathrm{Zn}(\mathrm{Oac})_{2} \cdot 2 \mathrm{H}_{2} \mathrm{O}$ was dissolved in $25 \mathrm{~mL}$ dichloromethane previously degassed under anitrogen atmosphere for 10 minutes. To this solution, $21 \mathrm{mg}(0.02 \mathrm{mmol})$ of $5,10,15$, 20-meso-tetrakis-(9H-2-fluorene-yl) porphyrin was added and degassed with nitrogen for about $10 \mathrm{~min}$. Under these conditions, the reaction flask was capped with rubber septum and kept stirring for $12 \mathrm{~h}$ protected from light. After that period the flask was connected to a reflux condenser surmounted by a $\mathrm{CaCl}_{2}$ trap 


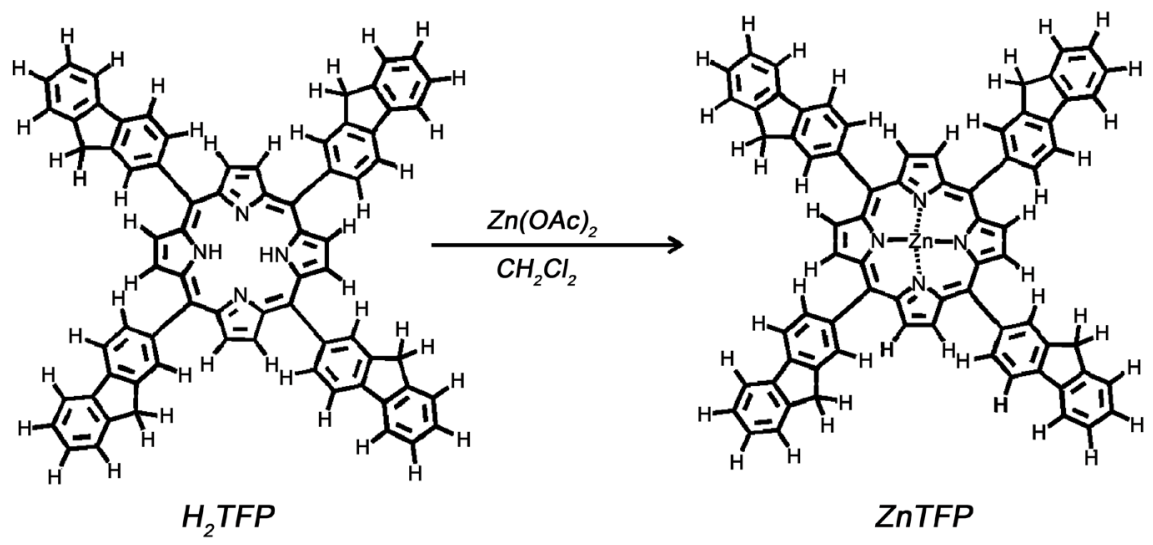

Scheme 2. Synthesis of Zinc-porphyrin complex.

and refluxed for more two additional hours. The solvent was evaporated and the resulting solid dried overnight on desiccator and dissolved in dichloro-methane. This solution was washed with a concentrated sodium hydrogen carbonate $(10 \%$ solution, $100 \mathrm{~mL}$ ) and after separation the resulting organic phase was dried on sodium sulfate anhydrous for $4 \mathrm{~h}$ protected from light. The solvent was evaporated and the solid dissolved in a small amount of dichloromethane. Silica gel was used for flash filtration employing dichloromethane: methanol $(9: 1 \mathrm{v} / \mathrm{v})$ as eluent solution. After solvent evaporation, the solid was treated with dichloromethane $(\sim 10 \mathrm{~mL})$, and filtered on cotton to remove any remaining impurities. The filtrate was recovered in a vial, placed inside of a flask capped with rubber septum under an atmosphere of methanol and left to stand for several days at room temperature protected from light. The obtained blue wish-violet solid was washed twice with cold methanol and dried in vacuum over fused $\mathrm{CaCl}_{2}$. The yield was $19.3 \mathrm{mg}(88 \%)$. Anal. Calcd for $\mathrm{C}_{72} \mathrm{H}_{44} \mathrm{~N}_{4} \mathrm{Zn}$ (1030.61g/mol): C, 83.90; H, 4.31; N, 5.44; Zn, 6.34; Found: C, 82.62; H, 6.18; N, 3.49; Zn, 2.57. The ${ }^{1} \mathrm{H}$-NMR spectrum of this compound is displayed in Figure 2. ${ }^{1} \mathrm{H}-\mathrm{NMR}$ (400 $\mathrm{MHz}, \delta \mathrm{ppm}\left(\mathrm{CDCl}_{3}\right.$ ): 9.08 (s, 8H, $\mathrm{CH}_{\beta \text {-pyrrolic }}$ ), $8.42\left(\mathrm{~s}, 4 \mathrm{H}, \mathrm{H}_{\text {fluorenyl }}, \mathrm{H}_{1}\right), 8.28$ (d, $\left.4 \mathrm{H}, J_{\mathrm{HH}}=0.1 \mathrm{~Hz}, \mathrm{H}_{\text {fluorenyl }}, \mathrm{H}_{4}\right), 8.17\left(\mathrm{~d}, 4 \mathrm{H}, J_{\mathrm{HH}} 0.02 \mathrm{~Hz}, \mathrm{H}_{\text {fluorenyl }}, \mathrm{H}_{3}\right), 8.07(\mathrm{~d}, 4 \mathrm{H}$, $\left.J_{\mathrm{HH}}=0.02 \mathrm{~Hz}, \mathrm{H}_{\text {fluorenyl }}, \mathrm{H}_{5}\right), 7.72\left(\mathrm{~d}, 4 \mathrm{H}, J_{\mathrm{HH}}=0.2 \mathrm{~Hz}, \mathrm{H}_{\text {fluorenyl }}, \mathrm{H}_{8}\right), 7.55(\mathrm{t}, 4 \mathrm{H}$, $\left.\mathrm{H}_{\text {fluorenyl }}, \mathrm{H}_{6}\right), 7.46\left(\mathrm{t}, 4 \mathrm{H}, \mathrm{H}_{\text {fluoreneyl }}, \mathrm{H}_{7}\right), 5.43\left(\mathrm{~s}, 8 \mathrm{H}, \mathrm{CH}_{\beta-\text { pyrrolic }}\right.$ ), and $4.22(\mathrm{~s}, 8 \mathrm{H}$, $4 \mathrm{CH}_{\text {2-fluorenyl }}$ ). FTIR ( $\left.\mathrm{cm}^{-1}, \mathrm{KBr}\right): 2920 \mathrm{~s}, 2850 \mathrm{sh}, 1710 \mathrm{~m}, 1460 \mathrm{~s}, 1400 \mathrm{w}, 1340 \mathrm{~m}$, $1280 \mathrm{~m}, 1220 \mathrm{~m}, 1000 \mathrm{~m}, 802 \mathrm{w}, 476 \mathrm{w}, 422 \mathrm{w}$. UV-vis (nm, dichloromethane), 427 (Soret); 552, 592 (Qs); $267 \pi-\pi^{\star}$ fluorenyl moieties.

\subsection{Fluorescence Lifetime Measurements}

The dye samples were dissolved in $3 \mathrm{~mL}$ of ethanol for fluorescence lifetime solution. To prevent inner filter effect, absorption measurements were carried out to ensure that the absorbances of the dyes were less or equal to 0.15 absorbance unit. Fluorescence decay was measured using Horiba Deltaflex fluorescence lifetime system using the time-correlated single-photon counting (TCSPC) technique with the PPD-850 picosecond photon detection module. The excitation source was $340 \mathrm{~nm}$ light-emitting diodes (Delta LED). 


\subsection{Fabrication of Solar Cell}

The photoanode was prepared by depositing a thin film of $\mathrm{TiO}_{2}$ on the conductive side of fluorine doped tin oxide (FTO) glass using a spin coater and sintered at $380^{\circ} \mathrm{C}$ for 2 hours [8] [9]. The $\mathrm{TiO}_{2}$ covered FTO glass was then immersed in a freshly prepared $5 \mathrm{mM}$ dye solution for a period of two hours. The counter electrode (cathode) was prepared by painting FTO glass with colloidal graphite. The dye-sensitized electrode and the carbon electrode were assembled to form a solar cell sandwiched with a redox $\left(\mathrm{I}^{-} / \mathrm{I}^{3-}\right)$ electrolyte solution. The active area of the cell was $5 \mathrm{~cm}^{2}$.

\subsection{Photovoltaic Properties Measurement}

The energy efficiencies of the fabricated DSSCs were measured using $150 \mathrm{~W}$ fully reflective solar simulator with a standard illumination with air-mass 1.5 global filter (AM $1.5 \mathrm{G}$ ) having an irradiance corresponding to 1 sun $\left(100 \mathrm{~mW} / \mathrm{cm}^{2}\right)$ purchased from Sciencetech Inc., London, Ontario, Canada and Reference 600 Potentiostat/Galvanostat/ZRA from Gamry Instruments (734 Louis Drive, Warminster, PA 18974). The tested solar cells were masked to an area of $5 \mathrm{~cm}^{2}$. Each cell performance value was taken as the average of three independent samples. The solar energy to electricity conversion efficiency $(\eta)$ was calculated based on the equation:

$$
\eta=\mathrm{FF} \times I_{\mathrm{sc}} \times V_{\mathrm{oc}}
$$

where, $\mathrm{FF}$ is the fill factor, $I_{\mathrm{sc}}$ is the short-circuit photocurrent density (mA $\mathrm{cm}^{-2}$ ), and $V_{\mathrm{oc}}$ is the open-circuit voltage (V) as listed in Table 3.

\section{Results and Discussion}

\section{1. ${ }^{1} \mathrm{H}$ NMR Spectra}

The proton NMR signals of free base $\mathrm{H}_{2}$ TFP is depicted in Figure 1. In its $\beta$ and meso positions are found the exocyclic protons with respect to the macrocyclic and local pyrrole currents which experience the deshielding influence of the latter. The signals for these protons are observed at low field ( $\delta$ from 7.46 to 8.42 $\mathrm{ppm}$ for the meso-fluorenylprotons and at $\delta$ from 8.5 to $8.9 \mathrm{ppm}$ for the $\beta$-pyrrole protons). The protons of the $\mathrm{N}-\mathrm{H}$ groups are exocyclic with respect to the local ring currents and endo-cyclic with respect to the macrocyclic current. Thus, the shielding effect of the latter prevails and the signals for the protons of the N-H groups are observed at very high field (from $\delta-1.4$ to $-4.4 \mathrm{ppm}$ ). [28] The proton NMR spectra of the metallic fluorenylporphyrins show clear differences relative to the free base fluorenylporphyrin. Upon complexation of the free base $\mathrm{H}_{2}$ TFP with zinc-acetate, the $\mathrm{H}_{\beta}$ protons of pyrrole ring (in $\mathrm{H}_{2}$ TFPat $\delta, 8.94$ $\mathrm{ppm}$ ) were shifted downfield (to $\delta 9.03 \mathrm{ppm}$ ). The inner imino hydrogens appear as a singlet at $-2.60 \mathrm{ppm}$, relative to $-2.75 \mathrm{ppm}$ for $\mathrm{H}_{2}$ TFP [28]. Thus the chemical shifts of ${ }^{1} \mathrm{H}-\mathrm{NMR}$ of free-base $\mathrm{H}_{2}$ TFP especially for $\mathrm{N}-\mathrm{H}$ protons, clearly shows the effect of non-planarity on the spectra of zinc-fluorenylporphyrin. In the neutral free base $\mathrm{H}_{2}$ TFP, for example, the $\mathrm{H}_{\alpha}$ and $\mathrm{H}_{\beta}$ signals appeared at $\delta$ 


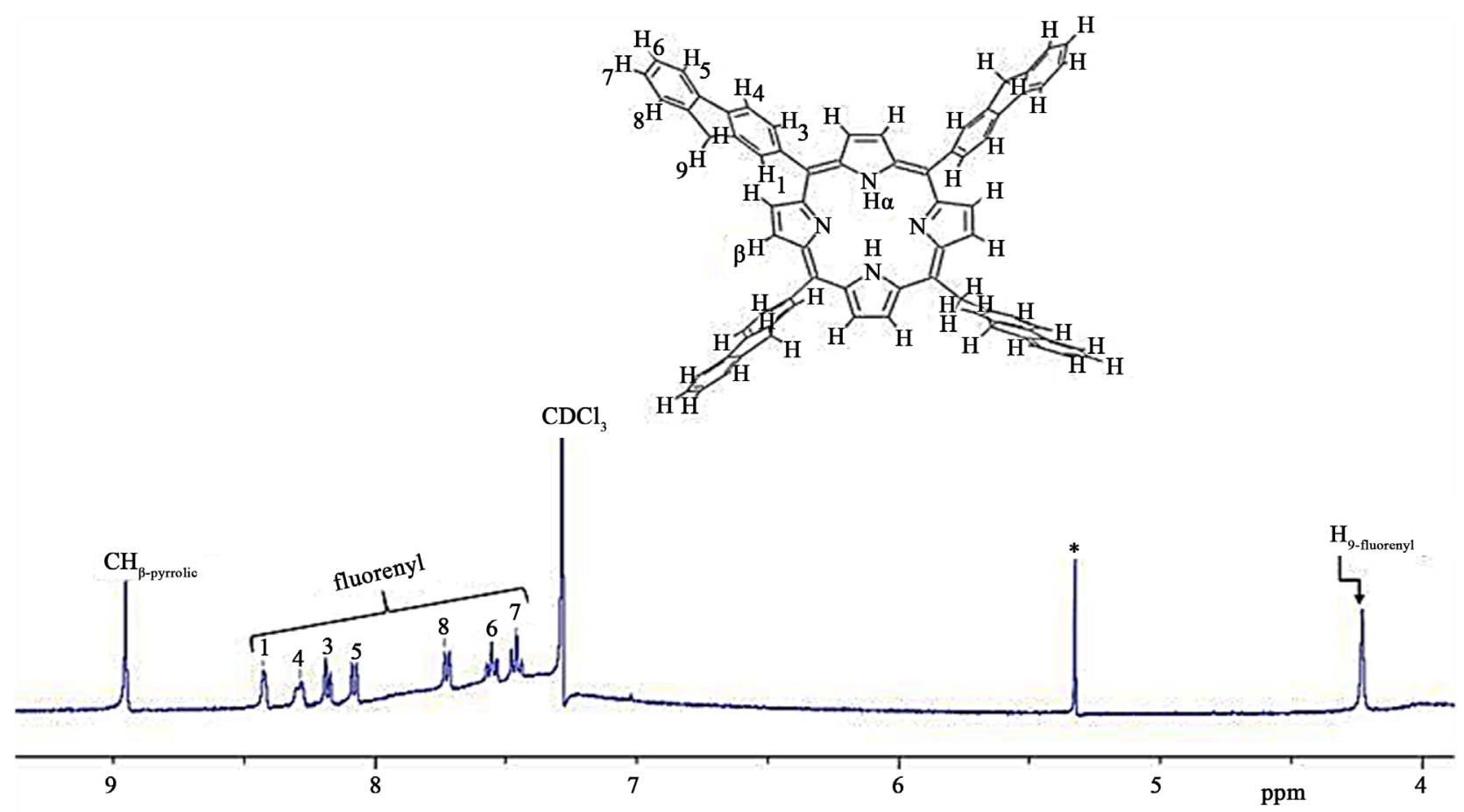

Figure 1. ${ }^{1} \mathrm{H}$-NMR spectra of free base $5,10,15,20$-meso-tetrakis- $\left(9 H\right.$-2-fluorene-yl) porphyrin, $\left(\mathrm{H}_{2} \mathrm{TFP}\right)$ with proton numbering for clarity, $1.0 \mathrm{mM}$ chloroform-d. Starred peaks are solvent impurities.

-2.60 and $8.94 \mathrm{ppm}$, respectively, while in the zinc-porphyrin complex (Figure 2 ), which has a severely distorted geometry with the $\mathrm{H}_{\beta}$ signal substituted and the slighted low field shifted $\mathrm{H}_{\beta}$ protons that appears as a quasi-doublet at $\delta 9.08$ $\mathrm{ppm}$. Those variations in the proton NMR spectra are ascribed to the energy cost on the non-planar distortion geometry depicted by the porphyrin structure during its complexes formation. The difference between these protons in regard to their intensity and signal splitting is related to the geometry instead of molecular symmetry [29] [30].

\subsection{Electronic Absorption Spectra}

The UV-visible absorption spectra in dichloromethane of the neutral free base $\left(\mathrm{H}_{2} \mathrm{TFP}\right)$ and its Zinc complex (ZnTFP) were carried out at room temperature and have been reported previously [31]. The measurements of these compounds were performed at different concentrations due to the difference in their absorption intensities; a more concentrated solution was used to display the Q bands and a less concentrated for the Soret band absorption of free and metallic porphyrin. The UV-visible spectra of neutral free base $\mathrm{H}_{2}$ TFP exhibit an intense Soret band with a maximum absorption around $424 \mathrm{~nm}$ and four $\mathrm{Q}$ bands characteristic of a porphyrin free base which are located at 521,556, and 598 and at 654 $\mathrm{nm}$, respectively. In addition, there is a wide and strong absorption band around $267 \mathrm{~nm}$, assigned to the $\pi-\pi^{*}$ intramolecular transitions of fluorenyl dyes if compared with the weak absorption in the UV range which is clearly apparent but absent for Tetra-Phenyl-Porphyrin (TPP) [31]. The absorption at $424 \mathrm{~nm}$ 


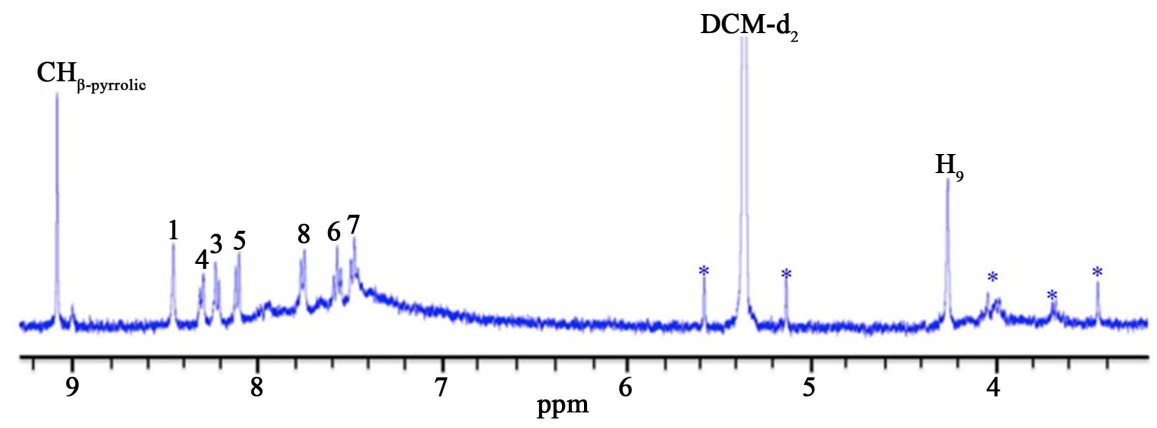

Figure 2. ${ }^{1} \mathrm{H}$-NMR spectra of zinc-fluorenylporphyrin complex $1.5 \times 10^{-5} \mathrm{M}$-dichloromethane- $\mathrm{d}_{2}$ at $298 \mathrm{~K}$. Starred peaks are solvent impurities.

corresponding to the $\mathrm{B}(0,0)$ band (Soret band, $\varepsilon=2.3 \times 10^{5} \mathrm{M}^{-1} \mathrm{~cm}^{-1}$ ) is slightly red shifted compared to $417 \mathrm{~nm}$ for TPP. This tendency in red shifting is also observed for the four $\mathrm{Q}$ bands. The metallic porphyrin complexes in the other hand, exhibit characteristic changes on the electronic spectra compared to $\mathrm{H}_{2}$ TFP.

Thus, the absorption spectra of $\mathrm{Zn}(\mathrm{II})$ porphyrin complex display a single Soret band which is a combination of the $\mathrm{Q}_{\mathrm{X}}$ and $\mathrm{Q}_{\mathrm{Y}}$ electronic transitions due to the $\mathrm{D}_{4} \mathrm{~h}$ symmetry of metallic porphyrins, instead of the $\mathrm{D}_{2} \mathrm{~h}$ low symmetry characteristic of free base porphyrins, with two discernible sub-bands $\left(\mathrm{Q}_{(1,0)}\right.$ and $\left.\mathrm{Q}_{(0-0)}\right)$ [32] [33]. Thus, the zinc-porphyrin exhibit an intense and red shifted band at $426 \mathrm{~nm}$ (Soret), $\varepsilon=3.8 \times 10^{5} \mathrm{M}^{-1} \mathrm{~cm}^{-1}$ ), together with two Q-bands in the visible range, one of moderated intensity located at $554 \mathrm{~nm}\left(\mathrm{Q}_{1-0}\right)$ attributed to a vibration component which is responsible in the withdrawn of intensity of the Soret band, however its molar absorptivity is almost constant in metalloporphyrins. A second Q-band is observed at $595 \mathrm{~nm}\left(\mathrm{Q}_{0-0}\right)$ which intensity in free-base porphyrins is defined for the difference between the transitions of two orbitals ( $a_{1 u}$ and $a_{2 u}$ orbitals) that lead to $E_{u}$ state, but if they are degenerated as occur in metallic-porphyrins this band practically does not exist [34] (Figure 3). An additional broad band is observed in the UV range which corresponds to $\pi-\pi^{*}$ absorption of the fluorenyl dyes. This absorption at $310 \mathrm{~nm}$ has different intensity than for the zinc complex as well for the free base $\mathrm{H}_{2} \mathrm{TFP}$ as consequence of the difference in electron's donor/withdraw exerted for the fluorenyl groups on the porphyrin chromophore geometrical conformation (distorted, freebase; butterfly zinc complex). Also, a slightly red shift on the UV band from $268 \mathrm{~nm}$ to $271 \mathrm{~nm}$ shows a deeply change in the metallic porphyrin derivative due to the remarkable geometry changes on the $5,10,15,20$-mesofluorenyl positions on the porphyrin ring.

\subsection{Steady State Fluorescence Studies}

Fluorescence spectra of $\mathrm{H}_{2}$ TFP and ZnTFP deployed in the fabrication of the DSSC were measured to investigate their emission characteristics. The spectra measured in dichloromethane by scanning from 500 to $800 \mathrm{~nm}$ with fixed excitation at $420 \mathrm{~nm}$ are displayed in Figure 4. Each of the dyes displayed different fluorescence behavior according with its chemical composition. Thus, the 


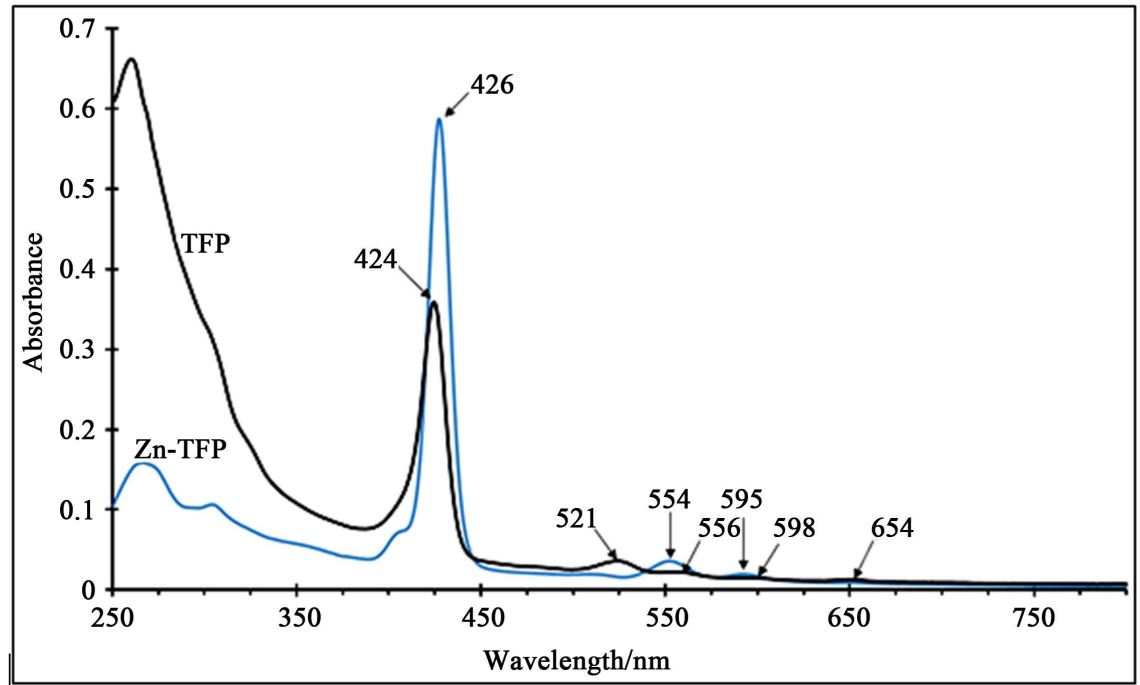

Figure 3. UV-VIS spectra of free base 5, 10, 15, 20 -meso-tetrakis-(9H-2-fluorene-yl) porphyrin, 1 ( $\left.\mathrm{H}_{2} \mathrm{TFP}\right)$, and $\mathrm{Zn}-5,10,15,20$-meso-tetrakis-(9H-2-fluorene-yl) porphyrinato (II) in dichloromethane.

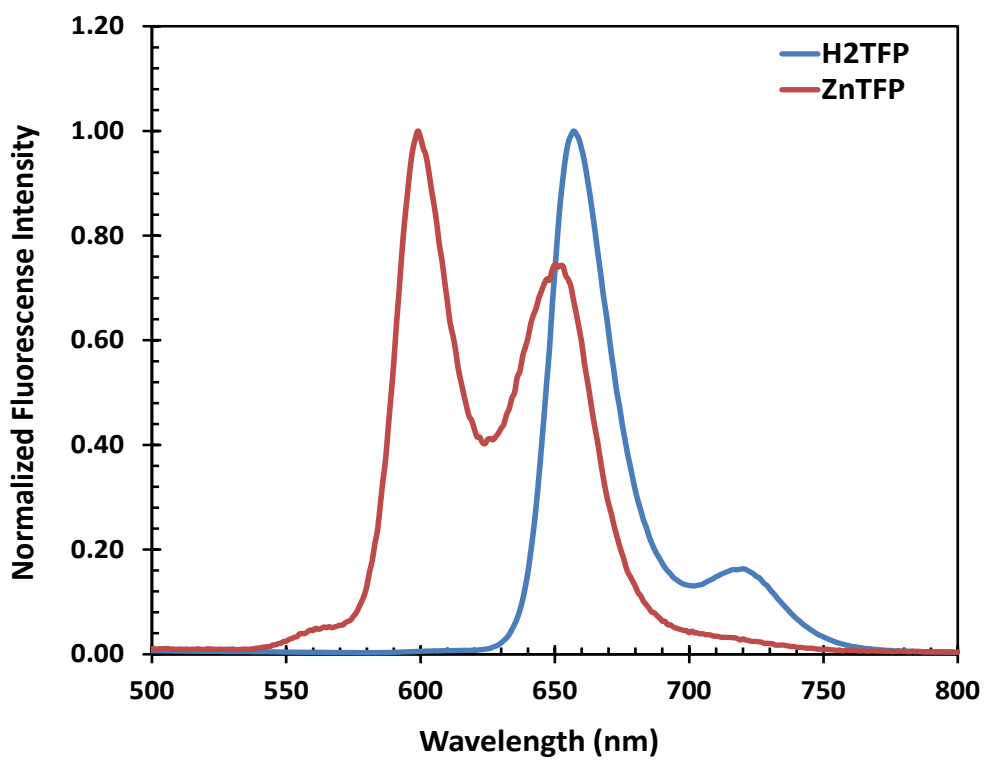

Figure 4. Fluorescence spectra of free base 5, 10, 15, 20-meso-tetrakis-(9H-2-fluorene-yl) porphyrin, $1\left(\mathrm{H}_{2} \mathrm{TFP}\right)$, and $\mathrm{Zn}-5,10,15,20$-meso-tetrakis-(9H-2-fluorene-yl) porphyrinato (II) in dichloromethane.

emission pattern of the free porphyrin resembles its UV-Vis absorption spectrum but the emission observed with the $\mathrm{Zn}$ complex shows to be very different. $\mathrm{H}_{2}$ TFP for example, displayed a red shift while ZnTFP exhibited a broadened fluorescence spectrum. The two emission peaks for the $\mathrm{H}_{2}$ TFP occurred at 658 $\mathrm{nm}$ and $720 \mathrm{~nm}$, whereas the fluorescence bands for ZnTFP occurred at $599 \mathrm{~nm}$ and $650 \mathrm{~nm}$, respectively. It could also be observed from the absorption spectra that the fluorescence peaks are the result of the metallic substitution that occurred on the first Q-bands of the porphyrin and these transitions are not dependent on the Soret band. 


\subsection{Fluorescence Lifetime Measurement}

As part of the photophysical studies on the porphyrin dyes, the fluoroscence lifetime measurement were carried out to determine the length of time the porphyrin molecules stay in the excited state before decay. Figure 5 and Table 1 show the fluorescence lifetime of the free-base $\left(\mathrm{H}_{2} \mathrm{TFP}\right)$ and the Zinc complex (ZnTFP). The fluorescence decay profiles were analyzed by two-exponential fit giving two components with lifetimes of $38.91 \mathrm{ps}$ and $1.38 \mathrm{~ns}$ for the free porphyrin and 58.11 ps and $5.27 \mathrm{~ns}$ for the zinc complex. The two lifetime is an indication of presence of two different species that decay at different rates. In dye sensitized solar cells the electons from the excited state are injected into the conduction band of titanium dioxide on which they dye is anchored. The injection process is also in competition with the normal relaxation pathways of the florophore in the excited state. Thus, understanding the decay process may help predict the fate of the electron in the excited state. Most organic molecules including porphyrin have short fluorescence lifetime which could easily be quenched by the iodide/triodideredoxcouple. Therefore dye molecules with short lifetime are more likely to have a short lifetime in the presence of the electrolyte.

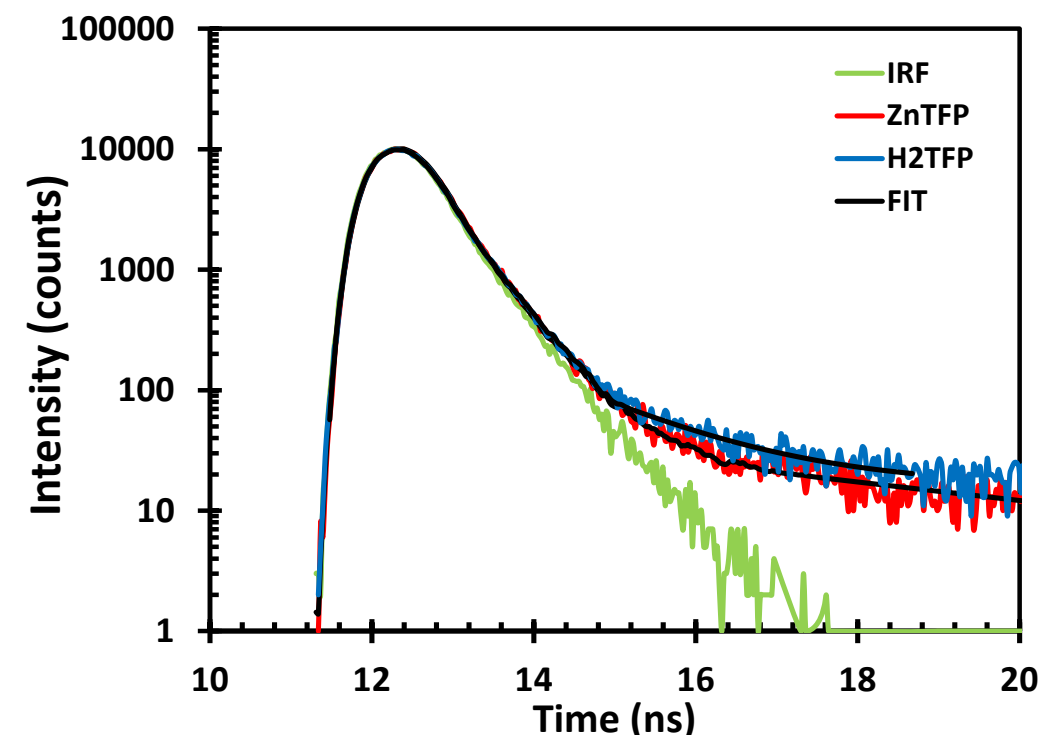

Figure 5. Fluorescence lifetime measurement of free base 5, 10, 15, 20-meso-tetrakis(9H-2-fluorene-yl) porphyrin, 1 ( $\left.\mathrm{H}_{2} \mathrm{TFP}\right)$, and $\mathrm{Zn}-5,10,15,20$-meso-tetrakis-(9H-2-fluorene-yl) porphyrinato (II) in dichloromethane.

Table 1. Fluorescence lifetime measurement of cyanine dyes free base 5, 10, 15, 20-mesotetrakis-(9H-2-fluorene-yl) porphyrin, 1 ( $\left.\mathrm{H}_{2} \mathrm{TFP}\right)$, and $\mathrm{Zn}-5,10,15,20$-meso-tetrakis(9H-2-fluorene-yl) porphyrinato (II) in dichloromethane.

\begin{tabular}{|c|c|c|c|}
\hline \multirow{2}{*}{$\underline{\text { Sample Name }}$} & \multicolumn{3}{|c|}{ Lifetime (ps) } \\
\hline & $\tau_{1}(\mathrm{ps})$ & $\tau_{2}(\mathrm{~ns})$ & $\chi^{2}$ \\
\hline $\mathrm{H}_{2}$ TFP & 38.91 & 1.38 & 1.10 \\
\hline ZnTFP & 58.11 & 5.27 & 1.09 \\
\hline
\end{tabular}




\subsection{FT-IR Spectroscopy}

The FT-IR of the $\mathrm{H}_{2}$ TFP and ZnTFP are displayed in Figure 6. In the free base, $\mathrm{H}_{2}$ TFP, the moderate IR bands at 3433 and $1540 \mathrm{~cm}^{-1}$ are attributed to the $\mathrm{NH}$ stretching vibrations, but they were absent in the spectra of the complexes, because the hydrogen atom in the $\mathrm{N}-\mathrm{H}$ bond were replaced by a transition metal ion. [35] The skeletal vibrations of the free porphyrin ring appear at 1553 and $1288 \mathrm{~cm}^{-1}$, respectively. A band of moderate intensity at $1450 \mathrm{~cm}^{-1}$ corresponds to $(\mathrm{C}-\mathrm{C})$ stretching of the fluorenyl dyes, and other two weak bands at 3030 and $2890 \mathrm{~cm}^{-1}$ are ascribed to the stretching of $(9 \mathrm{H})$ fluorenyl and $\left(\mathrm{H}_{\beta}\right)$ pyrrolic hydrogen, respectively. The vibrations implicated below $\sim 1000 \mathrm{~cm}^{-1}$ generally entail out-of-plane stretching for $\mathrm{C}-\mathrm{C}$ and $\mathrm{C}-\mathrm{H}$ groups in the fluorenyl chromophore. Additionally, combination bands in the $1500-500 \mathrm{~cm}^{-1}$ region involving non-planar $\mathrm{C}-\mathrm{H}$ vibrations have been reported previously for the fluorene dye [36] [37] [38] [39]. The IR results with $\mathrm{Zn}$ (II) metalloporphyrins, implies deep changes on the strong stretching composed by the two bands at 733 and 744 $\mathrm{cm}^{-1}$ observed for the $\mathrm{H}_{2} \mathrm{TFP}$ free base. On the $\mathrm{Zn}$ (II) metalloporphyrins (ZnTFP), these stretchings were splited into two weak bands shifted to 760 and $690 \mathrm{~cm}^{-1}$. Thus, the difference of energy between the splited signals for ZnTFP are mininal. These results are still directly related with the cost of stabilization energy encountered in the formation of metallic heterocyclic complexes.

\subsection{Field Emission Electron Microscopy (FESEM) Studies}

Studies on the morphology of the $\mathrm{TiO}_{2}$ electrode were further investigated using Field-Emission Scanning Microscopy Imaging (FESEM). Figure 7 shows the FESEM microscopic morphology of the porphyrin dye adsorbed nanocrystalline

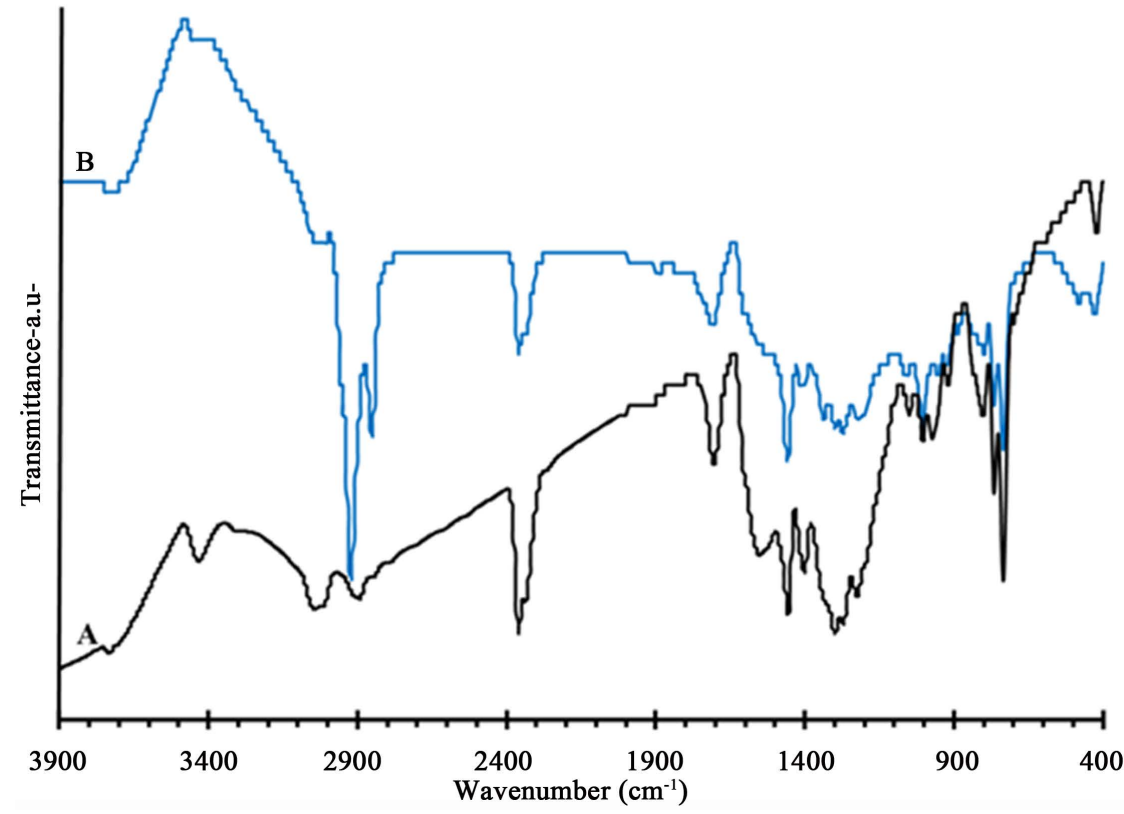

Figure 6. FT-IR spectra of (a) 5, 10, 15, 20-meso-tetrakis-(9H-2-fluorene-yl)porphyrin, $\mathrm{H}_{2}$ TFP (a), and (b) zinc-5, 10, 15, 20-meso-tetrakis-2-(9H-fluorenyl)porphyrinato (II), Zn-TFP (b), (KBr disk). 
$\mathrm{TiO}_{2}$ film. Only minor changes are observed in the surface morphology of the samples before and after dye application. The dye adsorbed $\mathrm{TiO}_{2}$ was finer than the bare $\mathrm{TiO}_{2}$ nanocrystalline film. Energy dispersive X-ray spectroscopic (EDS) mapping analysis of a nanocrystalline $\mathrm{TiO}_{2}$ partially sensitized with porphyrin dye is displayed in Figure 7(a). The part of the film containing the dye shows prominent peak for carbon, the predominant element in porphyrin. The peak for carbon is negligible in the part of the film without the porphyrin, instead the prominent titanium peaks are observed. EDS was also used for the chemical characterization of the porphyrin sensitized $\mathrm{TiO}_{2}$ in comparison with the bare $\mathrm{TiO}_{2}$ film. An intense carbon peak was observed in the spectrum of porphyrin dye-sensitized $\mathrm{TiO}_{2}$ film (Figure 7(b)) compared to the barely visible carbon peak in the spectrum of the bare $\mathrm{TiO}_{2}$ (Figure $7(\mathrm{c})$ ). Thus the results are consistent with the elemental composition of free porphyrin which is mainly

(a)

(c)
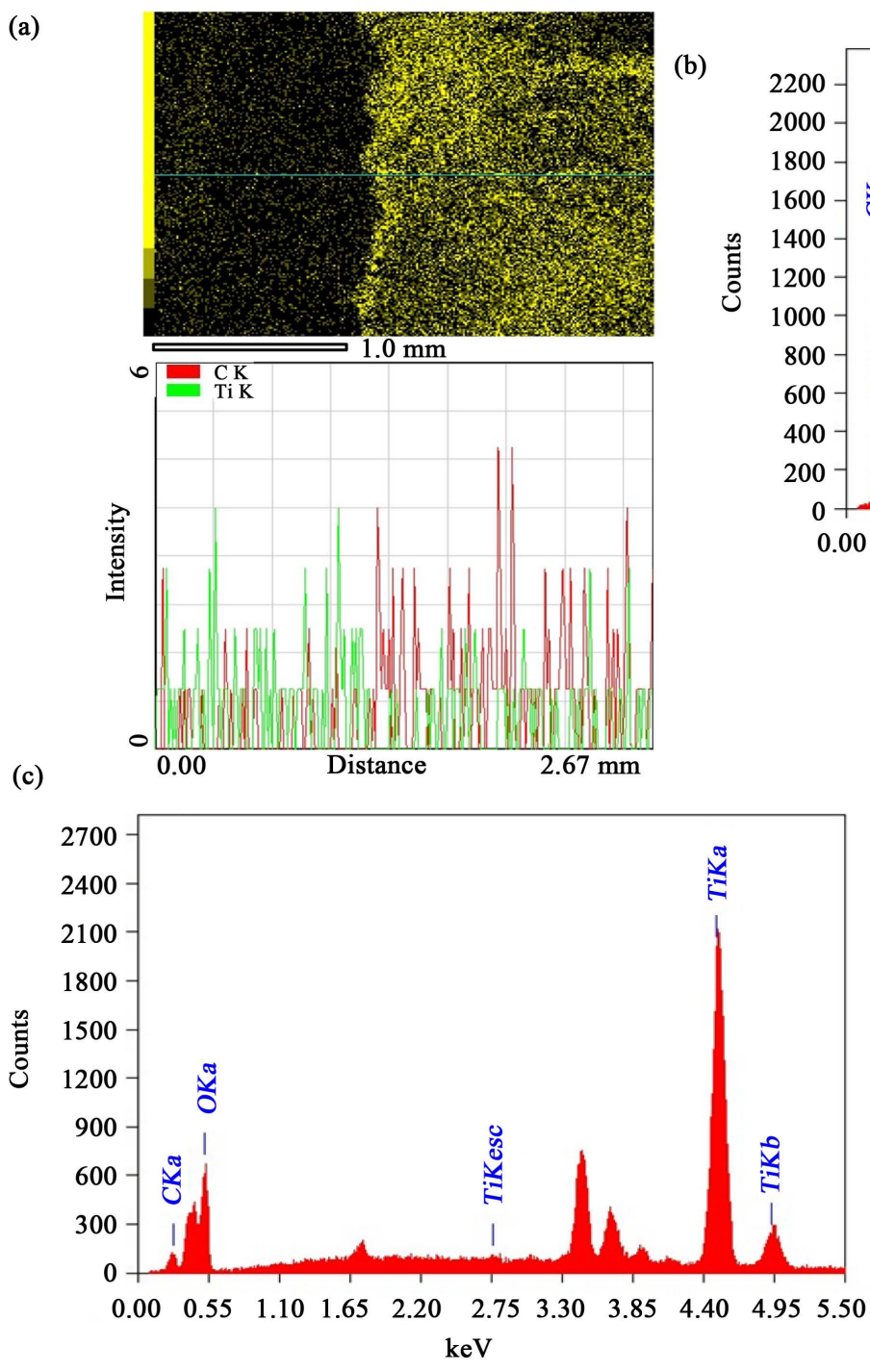

(b)

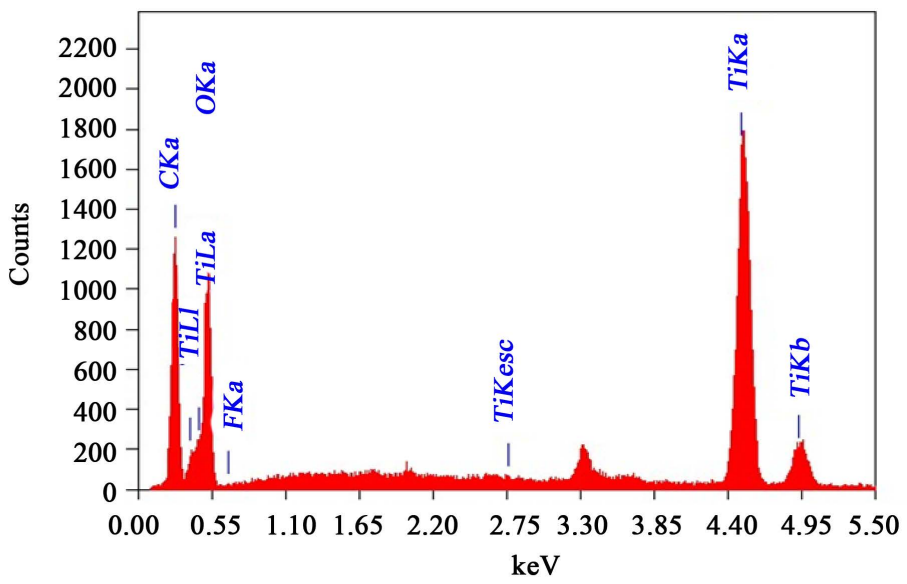

(d)

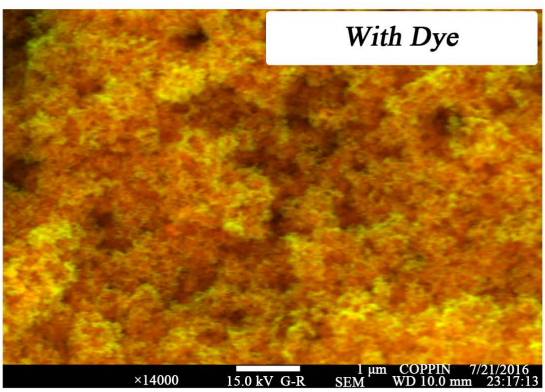

(e)

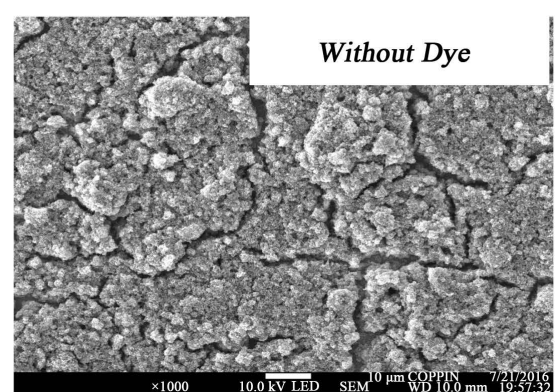

Figure 7. Field emission scanning electron microscopy and energy dispersive x-ray studies: (a) line profile analysis of a partially dyed $\mathrm{TiO}_{2}$ film on FTO glass (b) EDS spectrum of porphyrin dye sensitized $\mathrm{TiO}_{2}$ on FTO glass (c) EDS spectrum of bare TiO 2 coated FTO glass (d) FESEM image of porphyrin dye sensitized $\mathrm{TiO}_{2}$ film (e) FESEM image of bare $\mathrm{TiO}_{2}$ coated FTO glass. 
made up of carbon. The nanocrystalline nature of the $\mathrm{TiO}_{2}$ which increases the surface area of the titanium dioxide is clearly observed in Figure 7 (d) and Figure $7(e)$. The increased surface area allows more dye molecules to be anchored on it which ultimately increase the efficiency of the solar cell.

\subsection{Transmission Electron Microscopy Imaging Studies}

To confirm the adsorption of the porphyrin dyes on the $\mathrm{TiO}_{2}$ nanoparticles, the high-resolution images were taken by transmission electron microscopy as shown in Figure 8. To get the TEM images, the porphyrin dye powder was dissolved in acetone and the resulting solution filtered with a filter paper (VWR.com, grade 410) to remove residues. After that, $\mathrm{TiO}_{2}$ powder was added to form a mixture with the filtered dye solution. The mixture was then suspended for $20 \mathrm{~min}$ to ensure the adsorption of the dye into the $\mathrm{TiO}_{2}$. A drop of the dye mixture was subsequently deposited on a TEM grid and allowed to dry inside a hood overnight. A mixture of $\mathrm{TiO}_{2}$ and acetone was dried on another TEM grid and used as an external control. Anatase $\mathrm{TiO}_{2}$ nanoparticles were observed with a particle size range of $20-25 \mathrm{~nm}$ as shown in Figure 8. In Figure 8 (a) and Figure 8(b), the small spherical dyes of $1-3 \mathrm{~nm}$ were observed on the anatase $\mathrm{TiO}_{2}$ particles (the arrows in the images are guide to the dyes). Conversely, dye particles were not observed in the control as shown in Figure $8(\mathrm{c})$. Figure 8(d) and Figure 8(e) are a zoom-in images of one of the $\mathrm{TiO}_{2}$ crystals and its FFT pattern, respectively. The interplanar distance in the $\mathrm{TiO}_{2}$ crystal obtained by Fourier transform was $0.34 \mathrm{~nm}$ corresponding to the (101) plane of

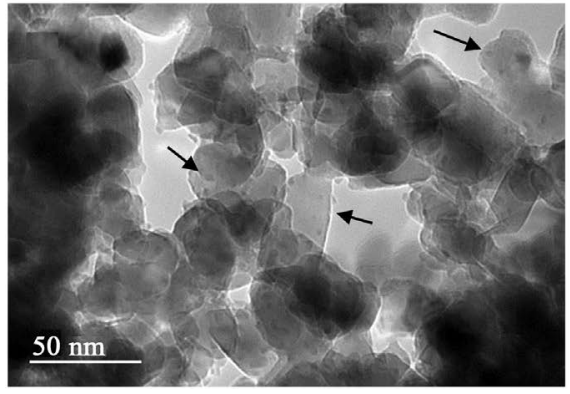

(a)

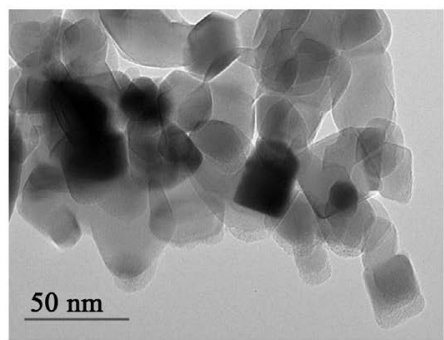

(c)

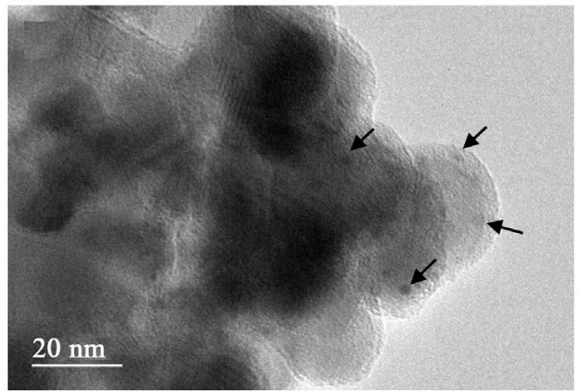

(b)

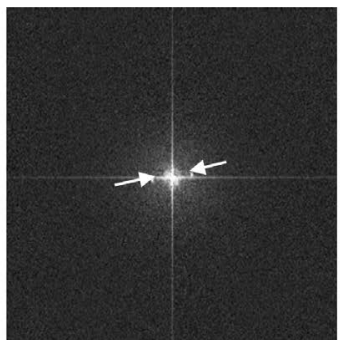

(e)

Figure 8. High-resolution TEM images of the porphyrin dye/ $\mathrm{TiO}_{2}$ samples and the $\mathrm{TiO}_{2}$ nanoparticles. (a) and (b) high resolution TEM images of porphyrin dye/ $\mathrm{TiO}_{2}$; and (c) of $\mathrm{TiO}_{2}$ nanoparticles without dye (d) zoom-in image of one of the $\mathrm{TiO}_{2}$ crystals (c), and (e) the FFT pattern of the zoom-in image. 
the anatase $\mathrm{TiO}_{2}$ powder. It is speculated that the adsorption between the $\mathrm{TiO}_{2}$ nanoparticles and the dyes results from the electrostatic binding, since the dyes do not have any functional groups which are able to induce any binding between them.

\subsection{Cyclic Voltammetry}

The standard redox process of a free base porphyrin is characterized for the two-electron transfer reaction with two reversible waves named $\mathrm{E}^{1} \mathrm{Ox}$ and $\mathrm{E}^{2} \mathrm{Ox}$, which are determinate by cyclic voltammetry. [40] The voltammogram of meso-tetrakis-phenyl porphyrin (TPP) had been used as a standard to interpret the electron transfer process that occurs on a large number of freebase and metallic porphyrins [41]. It is worth to mention that wave potentials on the meso positions are deeply affected by substituents around the porphyrin heterocyclic ring. In addition, the type of metal (hard or soft) and the degree of its oxidation state are directly related with the electron transfer changes on metallic porphyrins [42]. Felton et al. demonstrated that most of metallic porphyrins exhibit a constant potential difference between the first and the second macrocycle centered oxidation, or on the first and second macrocycle centered reductions. [43] Cyclic voltammetry, $\mathrm{CV}$, for free base $\mathrm{H}_{2} \mathrm{TFP}$ and its metallic derivatives were recorded using a one-compartment three-electrode cell, equipped with a platinum, $\mathrm{Pt}$, disk working electrode from Basi-Analytical Instruments (1.6 $\mathrm{mm}$ diameter), a platinum wire as auxiliary electrode, and all potentials were referenced to $\mathrm{Ag} / \mathrm{AgNO}_{3}(0.10 \mathrm{M}$, in acetonitrile) electrode. The working electrode was polished first using $0.30 \mu \mathrm{m}$ followed by $0.05 \mu \mathrm{m}$ alumina polish (BASi). The supporting electrolyte was $0.1 \mathrm{M}$ tetrabutylammonium perchlorate $\left(\mathrm{NBu}_{4} \mathrm{ClO}_{4}\right)$ and the measurements were made in N, N'- dimethylformamide, DMF. All potentials were converted to the SHE scale by adding $0.50 \mathrm{~V}$ to the experimental data [44].

The cyclic voltammetry were carried out on a Princeton Applied Research Versa STAT-3 potentiostate with samples degassed under a nitrogen flow before each scan. The synthesis and characterization of meso-tetrakis-fluorenylporphyrin, $\mathrm{H}_{2}$ TFP, in Scheme 1, has been previously reported [45] and for comparative purposes, the electrochemical and spectroscopic results of this chromophore and its metallic complexes are included in this study [46] [47]. The cyclic voltammogram of free base $\mathrm{H}_{2} \mathrm{TFP}$ in a $0.1 \mathrm{M} \mathrm{Bu}_{4} \mathrm{NClO} 4 / \mathrm{DMF}$ solution is illustrated in Figure 9(a) and summarized in Table 2. The CV of free base was recorded by applying three cycles, which shows two reversible redox couples with a peak potential, $E_{1 / 2}^{0}=+0.31 \mathrm{~V}$ and at $E_{1 / 2}^{0}=-0.79 \mathrm{~V}$ versus SHE. These two reversible reactions that occur at slightly different regions, correspond to the successive one electron redox reaction on the porphyrinic ring. The voltammogram shows another irreversible, strong, and broad wave at $E_{1 / 2}^{0}=-0.56 \mathrm{~V}$ that correspond at two electron transference reaction, attributed to the meso-fluorenylmoieties. This attribution is in agreement with similar meso-tetrakis aromaticporphyrins that shows identical electrochemical pattern according with Spiro et. al. [48]. In addition, the successive redox cycles applied on the same sample and at different scan rates do not shows great changes on the electrochemistry 


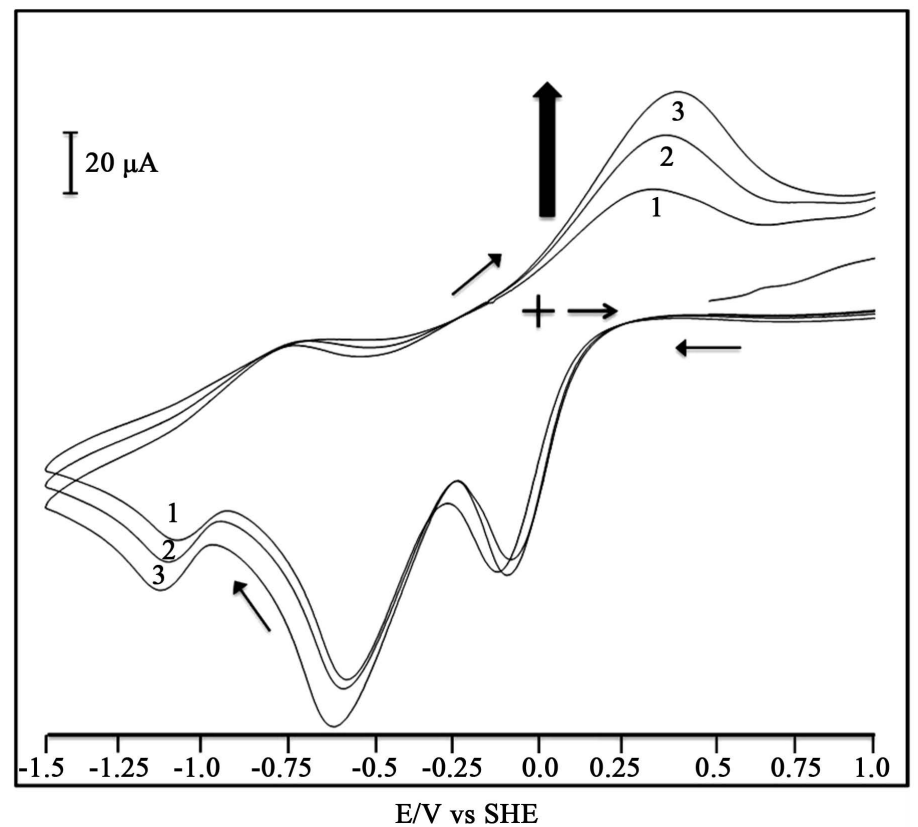

(a)

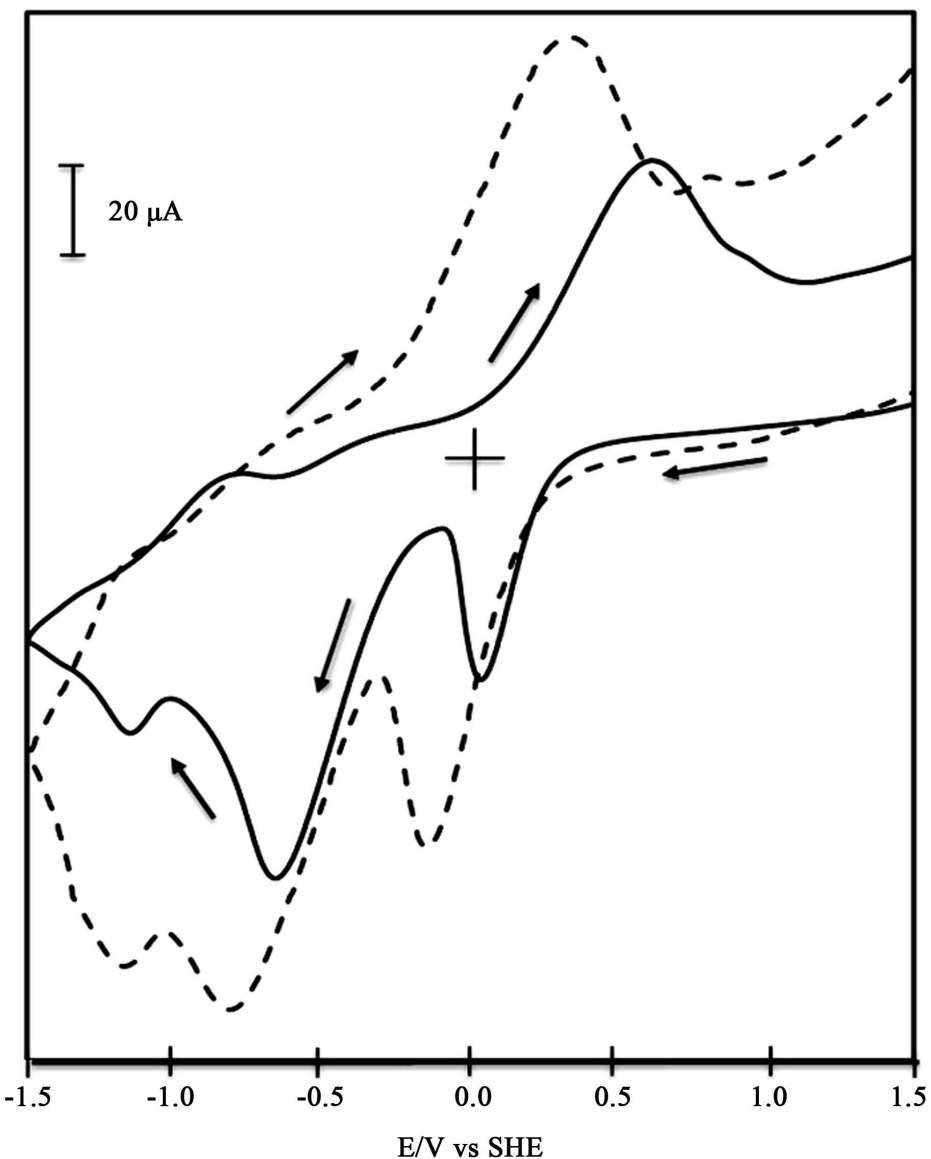

(b)

Figure 9. Cyclic voltammograms of (a) $\mathrm{H}_{2}$ TFP and (b) ZnTFP; $1.0 \times 10^{-6} \mathrm{moldm}^{-3}, \mathrm{~N}, \mathrm{~N}^{\prime}$ dimethylformamide, $0.1 \mathrm{moldm}{ }^{-3}$ tetrabuthylammonium perchlorate. Scan rate $50 \mathrm{mV} \cdot \mathrm{s}^{-1}$ (a) three cycles, and (b) Zn-TFP $+0.1 \mu \mathrm{M}$ of pyridine, (dashed line). Potentials recorded vs. $\mathrm{Ag} / \mathrm{AgNO}_{3}(0.1 \mathrm{M})$ reference electrode and converted to SHE by addition of $0.5 \mathrm{~V}$. 
Table 2. Redox potentials for free base $\mathrm{H}_{2} \mathrm{TFP}$, and metallic $[\mathrm{ZnTFP}]^{2+}$ complex.

\begin{tabular}{ccc}
\hline Compound & E1/2 $(\mathrm{V})^{\mathrm{a}}$ & Assignment \\
\hline $\mathrm{H}_{2} \mathrm{TfP}$ & -0.07 & Por 0/+ \\
& 0.31 & Por $+/-$ \\
& -0.56 & Fluorenyl 0/+ \\
& -1.07 & Por $+/ 2+$ \\
Zn-TfP & -0.79 & Por 2+/+ \\
& 0.57 & Zn II/III \\
& 0.03 & Zn III/II \\
& -0.63 & Fluorenyl 0/+ \\
Zn-TfP + pyridine & -0.86 & Por 0/+ \\
& -1.12 & Por +/0 \\
& 0.36 & Zn II/III \\
& -0.13 & Zn III/II \\
& -0.77 & Fluorenyl 0/+ \\
& -1.19 & Por 0/+ \\
& -1.13 & Por +/0 \\
& & \\
& &
\end{tabular}

${ }^{a}$ Potentials reported versus the SHE reference electrode in acetonitrile $(0.1 \mathrm{M})$ with samples dissolved in DMF. Scans recorded at $100 \mathrm{mV} \cdot \mathrm{s}^{-1}$ and $25^{\circ} \mathrm{C}$.

behavior, that could be related with the high stability showed by this porphyrin when exposed to air for long times but light protected. The peak potential separations $E_{p}$ between the anodic and cathodic peaks than for $\mathrm{H}_{2}$ TFP and its complexes ranged from $53 \mathrm{mV}$ to $67 \mathrm{mV}$ with an average of $61 \pm 0.002 \mathrm{mV}$. These values are close to the theoretical value of $59 \mathrm{mV}$ for a one-electron transfer reaction, that for a reversible process the peak width is given by the following relationship:

$$
E_{p / 2}-E_{p}=2.2\left[\frac{R T}{n F}\right]
$$

where $E_{p / 2}$ is the half-peak potential at the half value of the peak current, $E_{p}$, is the peak potential, $F$ is the Faraday constant and $n$ is the number of electrons in the reaction. The presence of metallic ions in the fluorenylporphyr in core makes the oxidation reaction of these complexes easier with the redox potentials shifted towards lower values.

The results of our experiments shows that zinc-fluorenyl porphyrin complex (ZnTFP) undergoes a one electron transfer process with a half wave potential, $E_{1 / 2}^{o}=0.57 \mathrm{~V}$ vs SHE in DMF (Figure 9(a)) for oxidation; while the reduction reaction shows to occur at $E_{1 / 2}^{0}=0.03 \mathrm{~V}$ vs SHE in a reversible one electron transfer as indicated by the peak current ratio, $\mathrm{i}_{\mathrm{a}} / \mathrm{i}_{\mathrm{c}}$ which is close to unity (herein, 1.0) at the scan rates investigated $(50-100 \mathrm{mV} / \mathrm{s})$. The peak separation between the anodic and cathodic peak potentials, Epa - Epc, shows to be close to 
$0.53 \mathrm{~V}$ (one electron transfer), which is attributed to a reversible electrochemistry process [49]. Thus, the one electron donating/withdrawing in a symmetrical process (among its reversible characteristic), means that this material is very stable. Some broadening occurred, however, due to uncompensated resistance. Similar as observed on other free base porphyrins, the fluorenyl group on the pyrrolic ring makes ZnTFP easier to reduce [50]. Therefore, the presence of aromatic groups in the meso positions weakens the interaction between the metal and porphyrin by turning easier the electron transfer reactions. In addition, cyclic voltammograms were recorded after the addition of a diluted pyridine solution ( $1.25 \mu \mathrm{M}$, see Figure 9(b)-dotted curve), in that a symmetrical shift to low potentials with $\Delta E_{1 / 2}^{0}=0.21 \mathrm{~V}$ and $\Delta E_{1 / 2}^{o}=0.27 \mathrm{~V}$ ascribed to the oxidation of the $\mathrm{Zn}^{\mathrm{III}}$ ion. This process occur in parallel to the raise of well defined peak current ratio, ia/ic $(\Delta i=12 \mu \mathrm{A})$ attributed to an enhancement in the zinc-complex geometry $\left(\mathrm{O}_{\mathrm{h}}\right)$, instead of the butterfly associated with the square planar coordination.

\subsection{I-V Performance}

Figure 10 and Table 3 show the current-voltage characteristics the free base, $\mathrm{H}_{2}$ TFP, and metallic meso-tetrakis-2-(H9-fluorenyl) porphyrin. The current-voltage curves reveal a significant difference in the photovoltaic performance of the free base porphyrin $\left(\mathrm{H}_{2} \mathrm{TFP}\right)$ and ZnTFP sensitized solar cell. A higher efficiency was obtained from devices fabricated with the free porphyrin

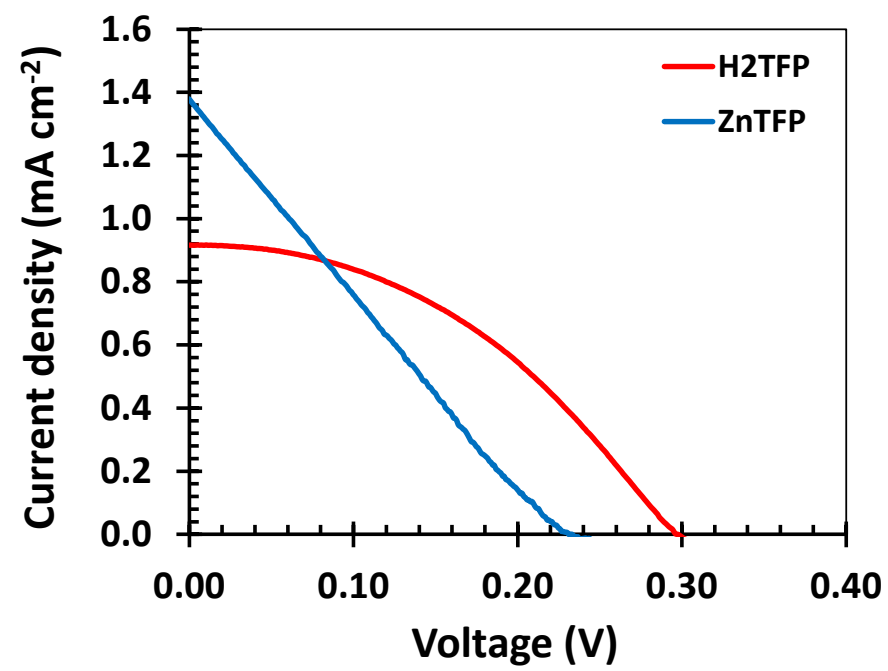

Figure 10. Current and Voltage Characteristics of dye sensitized solar cells fabricated with free base $\mathrm{H}_{2}$ TFP and metallic meso-tetrakis-2-(H9-fluorenyl) porphyrin coordinated to $\mathrm{Zn}$ (II).

Table 3. Current and voltage characteristics for the porphyrin dye sensitized solar cells.

\begin{tabular}{ccccccc}
\hline DYE & $\operatorname{Isc}\left(\mathrm{mA} / \mathrm{cm}^{2}\right)$ & $\operatorname{Voc}(\mathrm{V})$ & $\operatorname{Imp}\left(\mathrm{mA} / \mathrm{cm}^{2}\right)$ & $\operatorname{Vmp}(\mathrm{V})$ & Fill Factor & Efficiency $(\%)$ \\
\hline $\mathrm{H}_{2}$ TFP & 0.92 & 0.31 & 0.64 & 0.18 & 0.40 & 0.11 \\
$\mathrm{ZnTFP}$ & 1.38 & 0.25 & 0.72 & 0.11 & 0.23 & 0.08 \\
\hline
\end{tabular}


(0.11\%) compared with that fabricated with Zn complex (0.08\%). The higher efficiency of the free porphyrin compared to the $\mathrm{Zn}$ complex could be due to an efficient interaction between the $\mathrm{TiO}_{2}$ surface and the free porphyrin. Such interaction favors the injection of electron from the dye into the conduction band of the titanium dioxide. Specifically, the geometry orientation and flexibility changes when the metal is inserted into the porphyrin ring. Thus, the rigidity of the resulting coordinated porphyrin reduces the interaction of the dye with the $\mathrm{TiO}_{2}$ surface leading to a decrease in the electron transfer efficiency of the cell. Therefore, the efficiency values on these dyes could be improved when anchoring groups that facilitate charge transfers attached to these porphyrin molecules.

\subsection{Electrochemical Impedance Spectroscopy}

Electrochemical impedance measurements on the solar cells fabricated using free base $\mathrm{H}_{2}$ TFP and the metal complex (ZnTFP) were carried out to understand charge transfer and energetics of charge transport and recombination. The impedance measurements were carried out at frequencies between 0 and $100 \mathrm{KHz}$. Figure 11 shows the Nyquist plots (a) and Bode plots (b) of $\mathrm{H}_{2}$ TFP and ZnTFP,

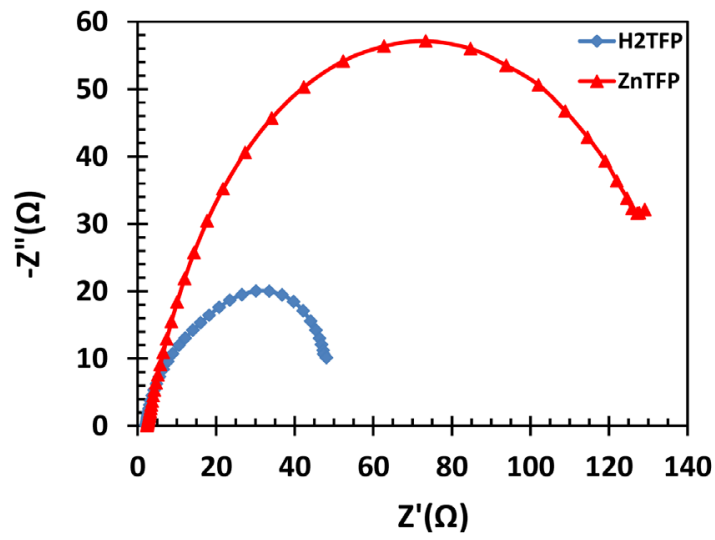

(a)

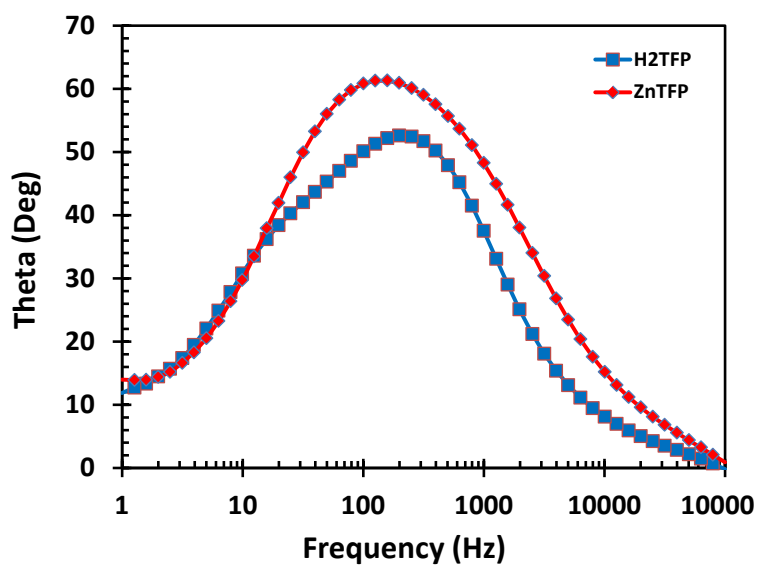

(b)

Figure 11. Impedance studies of the fabricated devices: (a) Nyquist plot of the dye sensitized solar cells fabricated using $\mathrm{H}_{2}$ TFP (blue) and ZnTFP (blue); (b) Bode plot of dye sensitized solar cells fabricated using $\mathrm{H}_{2}$ TFP (blue) and ZnTFP (red). 
respectively. The arc in the high frequency region is usually associated with the charge transfer resistance at the interface between the redox couple/electrolyte and counter electrode whereas the arc in the low frequency region is ascribed to the resistance of the transport of the injected electrons within the $\mathrm{TiO}_{2}$ film. The results seen here are consistent with the IV data. The impedance measurement also shows less overall resistance for the free porphyrin $(50 \Omega)$ compared with the zinc complex $(130 \Omega)$. The position of the low frequency peak of the Bode plot provides information on the lifetime of the photo induced electrons via the equation:

$$
\tau=1 /(2 \pi f)
$$

where, $f$ is the frequency of superimposed ac voltage. Thus, $\mathrm{H}_{2}$ TFP was found to have a longer lifetime than ZnTFP.

\subsection{Density Functional Theory (DFT) Calculations}

Density functional calculations were used to optimize the geometry of fluorenylporphyrin, $\mathrm{H}_{2}$ TFP, molecule using the software Spartan 16 from Wave function. All geometries were computed using the $\omega$ B97X-D density functional theory method. Geometry optimization was performed using $6-31 \mathrm{G}^{*}$ basis set. These calculations were used to calculate the highest occupied molecular orbital (HOMO) and the lowest unoccupied molecular orbital (LUMO) energies of free base and metallic meso-tetrakis-2-(H9-fluorenyl) porphyrin coordinated to $\mathrm{Zn}$ (square planar complex).

Figure 12(a) and Figure 12(b), show the Lewis and 3D structures of fluorene-porphyrin, respectively. Similarly, Figure 12(c) and Figure 12(d) show the

(a)

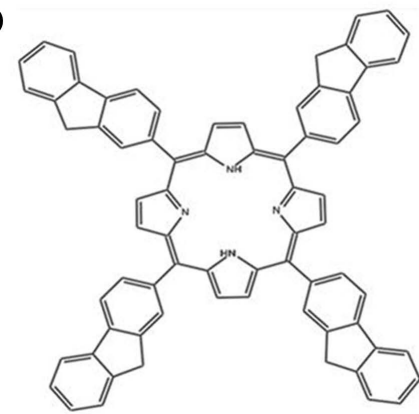

(c)

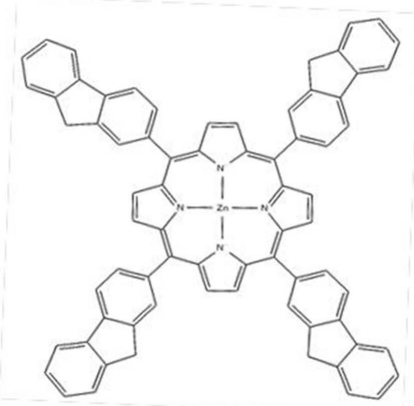

(b)

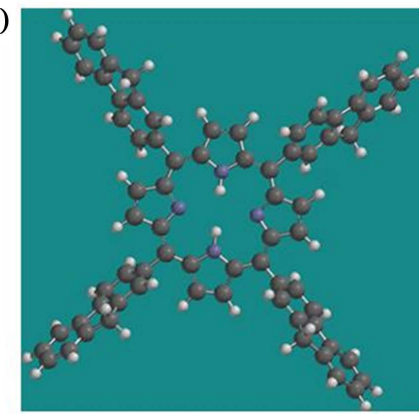

(d)

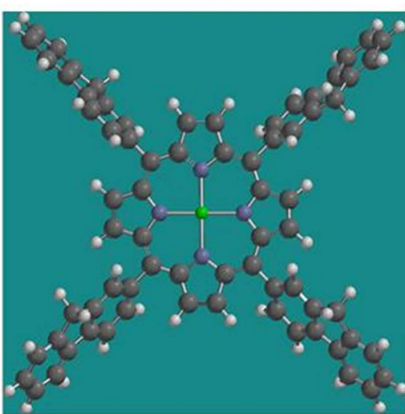

Figure 12. Lewis structure ((a), (c)) and 3D structure ((b), (d)) of free porphyrin ((a), (b)) and metallic porphyrin $((\mathrm{c}),(\mathrm{d}))$. 
Lewis and 3D structures of metallic meso-tetrakis-2-(H9-fluorenyl) porphyrin, respectively. The calculations gave a result for the $\mathrm{HOMO}$ as $-6.29 \mathrm{eV}$ and the result for the LUMO found to be $-0.87 \mathrm{eV}$. Thus, the difference in the HOMO and LUMO which is the band gap was $5.42 \mathrm{eV}$. The calculations for the metallic compound gave a result for the HOMO as $-6.36 \mathrm{eV}$ and the result for the LUMO as $-0.77 \mathrm{eV}$. The difference in the HOMO and LUMO which is the band gap was $5.59 \mathrm{eV}$. The HOMO and LUMO surfaces and orbital energy diagrams for the free base is displayed in Figure 13(a) and Figure 13(b) and that of metallic porphyrin are shown in Figure 13(c) and Figure 13(d), respectively. The blue and red regions in all the figures represent the positive and negative values of these orbitals, respectively.

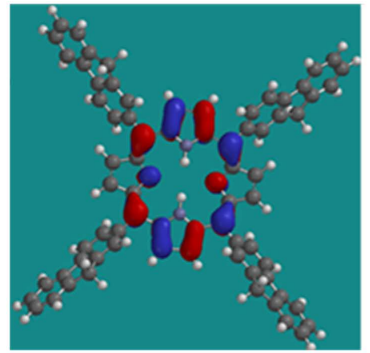

HOMO $\left(\mathrm{H}_{2}\right.$ TFP $)$

(a)

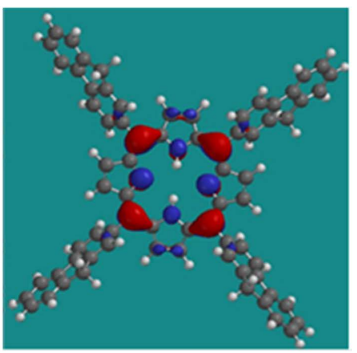

LUMO $\left(\mathrm{H}_{2}\right.$ TFP $)$

(b)

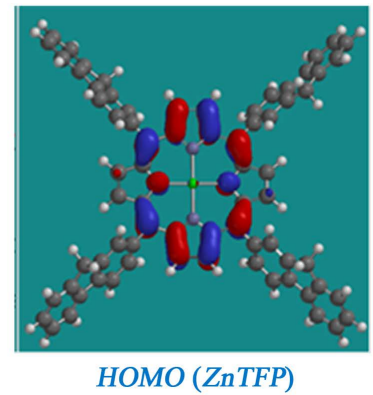

(c)

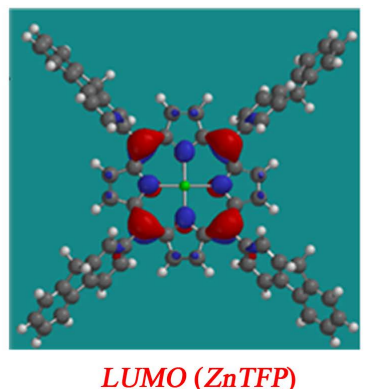

(d)

Figure 13. LUMO Energy diagram and surface ((a), (c)) and HOMO energy diagram and surface ((b), (d)) of the free Porphyrin ((a), (b)) and metallic porphyrin ((c) (d)).

\subsection{Energy Diagram}

In the presence of solar energy, porphyrin dye molecules (S) adsorbed on the $\mathrm{TiO}_{2}$ film absorb photon and make a transition from the ground state or highest occupied molecular orbitals (HOMO) to the excited state or the lowest unoccupied molecular orbital (LUMO) state as displayed in Figure 14. The photoexcited dye species $\left(\mathrm{S}^{*}\right)$ injects an electron into the conduction band of $\mathrm{TiO}_{2}$ electrode and becomes oxidized $\left(\mathrm{S}^{+}\right)$. The oxidized dye species subsequently accept an electron from the electrolyte $\left(\mathrm{I}^{-}\right)$and the ground state of the dye (S) is restored. The injected electron is transported through the mesoporous $\mathrm{TiO}_{2}$ film to the FTO layer and is conducted through an external circuit to a load where the work done is delivered as electrical energy. The electron from the external load diffuses to the cathode where it gets transferred to the electrolyte $\left(\mathrm{I}^{3-}\right)$. 


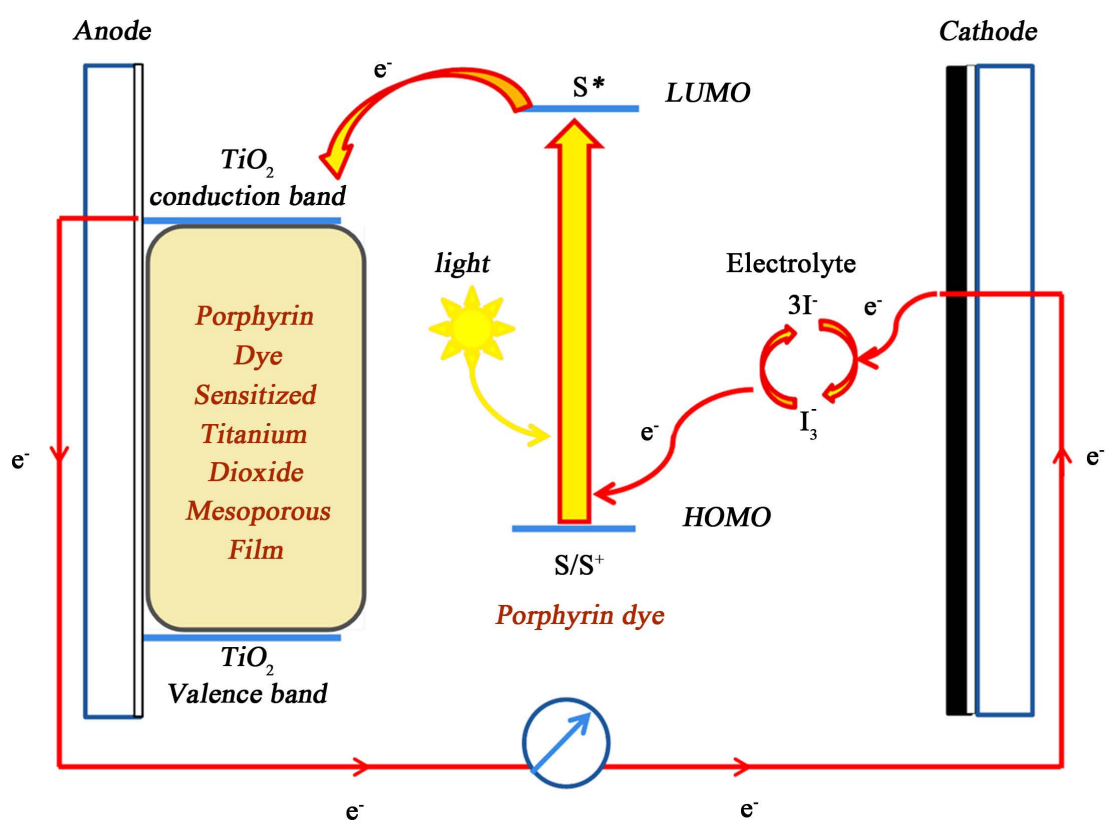

Figure 14. Energy diagram of porphyrin dye sensitized solar cell.

\section{Conclusion}

Two different porphyrin dyes were used to fabricate dye sensitized solar cells. The two porphyrin complexes comprised of a metal-free 5, 10,15, 20-meso-tetrakis-(9H-2-fluorene-yl) porphyrin $\left(\mathrm{H}_{2} \mathrm{TFP}\right)$ and its Zinc complex (ZnTFP). UV-Vis, Fluorescence, and Fourier Transformed Infrared measurements of the two dyes were carried out to evaluate their absorption, emission and binding characteristics. The Soret band of the dyes was almost the same while changes in the Q-band were observed. This observation was also confirmed in the fluorescence data where changes in peak intensity were due to Q-band. The surface morphology and elemental analysis of the porphyrin dye sensitized photoanodes were determined using Field Emission Scanning Electron Microscopy Imaging and Transmission Electron Microscopy Imaging. The nanocrystalline nature of the $\mathrm{TiO}_{2}$ and their interaction with the dyes were clearly observed under the electron microscopes. Cyclic voltammetry studies, current-voltage characteristics and the electrochemical impedance spectroscopic studies were also carried out. Solar-to-electric energy efficiency of $\mathrm{H}_{2}$ TFP dye sensitized solar cell was higher $(0.11 \%)$ than that of the zinc complex $(0.08 \%)$. Thus the metal free porphyrin generated more power than the zinc complex under similar conditions. These efficiencies could be higher when anchoring groups are attached to the porphyrins. The free base $\mathrm{H}_{2}$ TFP chromophore was found to possess the best photosensitization effect among the two porphyrin dyes studied which has been attributed by the flexibility of the dye to interact.

\section{Acknowledgements}

The work was financially supported by the University of Maryland System (Wilson E. Elkins Professorship), Constellation, an Exelon Company (E2-Ener- 
gy to Educate grant program) and Dept. of Education (SAFRA Title III Grant). The authors are also grateful to the Institution of Advancement, Coppin State University, for administrative help. The content is exclusively the responsibility of the authors and does not necessarily represent the official views of the funding agencies.

\section{References}

[1] Wei, D. (2010) Dye Sensitized Solar Cells. International Journal of Molecular Sciences, 11, 1103-1113. https://doi.org/10.3390/ijms11031103

[2] Sugathan, V., John, E. and Sudhakar, K. (2015) Recent Improvements in Dye Sensitized Solar Cells: A Review. Renewable and Sustainable Energy Reviews, 52, 54-64.

[3] Gratzel, M. (2003) Dye-Sensitized Solar Cells. Journal of Photochemistry and Photobiology $C, 4,145-153$.

[4] Grätzel, M. (2005) Solar Energy Conversion by Dye-Sensitized Photovoltaic Cells. Inorganic Chemistry, 44, 6841-6851. https://doi.org/10.1021/ic0508371

[5] O’Regan, B. and Gratzel, M. (1991) A Low-Cost, High-Efficiency Solar Cell Based on Dye-Sensitized Colloidal $\mathrm{TiO}_{2}$ Films. Nature, 353, 737-740. https://doi.org/10.1038/353737a0

[6] Hug, H., Bader, M., Mair, P. and Glatzel, T. (2014) Biophotovoltaics: Natural Pigments in Dye-Sensitized Solar Cells. Applied Energy, 115, 216-225.

[7] Hao, S., Wu, J., Huang, Y. and Lin, J. (2006) Natural Dyes as Photosensitizers for Dye-Sensitized Solar Cell. Solar Energy, 80, 209-214.

[8] Amadi, L., Jenny, S.S., Ahmed, A., Brown, N., Yadav, S., Brown, D., Ghann, W., Gayrama, A., Jiru, M. and Uddin, J. (2015) Creation of Natural Dye Sensitized Solar Cell by Using Nanostructured Titanium Oxide. Nanoscience and Nanoengineering, 3, 25-35. https://doi.org/10.13189/nn.2015.030301

[9] Ghann, W., Kang, H., Sheikh, T., Yadav, S., Chavez-Gil, T., Nesbitt, F. and Uddin, J. (2017) Fabrication, Optimization and Characterization of Natural Dye Sensitized Solar Cell. Scientific Reports, 7, Article No. 41470.

https://doi.org/10.1038/srep41470

[10] Ludin, N.A., Al-Alwani Mahmoud, A.M., Bakar Mohamad, A., Kadhum, A.A.H., Sopian, K. and Abdul Karim, N.S. (2014) Review on the Development of Natural Dye Photosensitizer for Dye-Sensitized Solar Cells. Renewable and Sustainable Energy Reviews, 31, 386-396.

[11] Yadav, S., Jenny, S.S., Ahmed, A., Amadi, L., Nesbitt, F., Ward, A.W.G., Brown, D., Uddin, J. and Uddin, N. (2015) Natural Light-Harvesting Sensitizers for Dye Sensitized Solar Cell. Energy and Environmental Engineering, 3, 94-99. https://doi.org/10.13189/eee.2015.030403

[12] Shalini, S., Balasundara Prabhu, R., Prasanna, S., Mallick, T.K. and Senthilarasu, S. (2015) Review on Natural Dye Sensitized Solar Cells: Operation, Materials and Methods. Renewable and Sustainable Energy Reviews, 51, 1306-1325.

[13] Wu, W., Guo, F., Li, J., He, J. and Hua, J. (2010) New Fluoranthene-Based Cyanine Dye for Dye-Sensitized Solar Cells. Synthetic Metals, 160, 1008-1014.

[14] Akhtaruzzaman, M., Islam, A., Yang, F., Asao, N., Kwon, E., Singh, S.P., Han, L. and Yamamoto, Y. (2011) A Novel Metal-Free Panchromatic $\mathrm{TiO}_{2}$ Sensitizer Based on a Phenylenevinylene-Conjugated Unit and an Indoline Derivative for Highly Efficient Dye-Sensitized Solar Cells. Chemical Communications, 47, 12400-12402. https://doi.org/10.1039/c1cc15580f 
[15] Chen, C.Y., Wang, M., Li, J.Y., Pootrakulchote, N., Alibabaei, L., Ngoc-Le, C.H., Decoppet, J.D., Tsai, J.H., Gratzel, C., Wu, C.G., Zakeeruddin, S.M. and Gratzel, M. (2009) Highly Efficient Light-Harvesting Ruthenium Sensitizer for Thin-Film DyeSensitized Solar Cells. ACS Nano, 3, 3103-3109. https://doi.org/10.1021/nn900756s

[16] Klein, C., Nazeeruddin, M.K., Censo, D.D., Liska, P. and Grätzel, M. (2004) Amphiphilic Ruthenium Sensitizers and Their Applications in Dye-Sensitized Solar Cells. Inorganic Chemistry, 43, 4216-4226. https://doi.org/10.1021/ic049906m

[17] Bhaumik, J., Weissleder, R. and McCarthy, J.R. (2009) Synthesis and Photophysical Properties of Sulfonamidophenyl Porphyrins as Models for Activatable Photosensitizers. The Journal of Organic Chemistry, 74, 5894-5901. https://doi.org/10.1021/jo900832y

[18] Daphnomili, D., Landrou, G., Prakash Singh, S., Thomas, A., Yesudas, K., Bhanuprakash, K., Sharma, G.D. and Coutsolelos, A.G. (2012) Photophysical, Electrochemical and Photovoltaic Properties of Dye Sensitized Solar Cells Using a Series of Pyridyl Functionalized Porphyrin Dyes. RSC Advances, 2, 12899-12908. https://doi.org/10.1039/c2ra22129b

[19] Daphnomili, D., Sharma, G.D., Biswas, S., Justin Thomas, K.R. and Coutsolelos, A.G. (2013) A New Porphyrin Bearing a Pyridinylethynyl Group as Sensitizer for Dye Sensitized Solar Cells. Journal of Photochemistry Photobiology A: Chemistry, 253, 88-96.

[20] Gou, F., Jiang, X., Li, B., Jing, H. and Zhu, Z. (2013) Salicylic Acid as a Tridentate Anchoring Group for azo-Bridged Zinc Porphyrin in Dye-Sensitized Solar Cells. ACS Applied Materials \& Interfaces, 5, 12631-12637. https://doi.org/10.1021/am403987b

[21] Hart, A.S., Chandra, B.K.C., Gobeze, H.B., Sequeira, L.R. and D’Souza, F. (2013) Porphyrin-Sensitized Solar Cells: Effect of Carboxyl Anchor Group Orientation on the Cell Performance. ACS Applied Materials \& Interfaces, 5, 5314-5323. https://doi.org/10.1021/am401201q

[22] He, H., Gurung, A. and Si, L. (2012) 8-Hydroxylquinoline as a Strong Alternative Anchoring Group for Porphyrin-Sensitized Solar Cells. Chemical Communications, 48, 5910-5912. https://doi.org/10.1039/c2cc31440a

[23] Higashino, T. and Imahori, H. (2015) Porphyrins as Excellent Dyes for Dye-Sensitized Solar Cells: Recent Developments and Insights. Dalton Transactions, 44, 448463. https://doi.org/10.1039/C4DT02756F

[24] Lan, C.M., Wu, H.P., Pan, T.Y., Chang, C.W., Chao, W.S., Chen, C.T., Wang, C.L., Lin, C.Y. and Diau, E.W.G. (2012) Enhanced Photovoltaic Performance with CoSensitization of Porphyrin and an Organic Dye in Dye-Sensitized Solar Cells. Energy \& Environmental Science, 5, 6460-6464. https://doi.org/10.1039/c2ee21104a

[25] Mai, C.-L., Moehl, T., Hsieh, C.-H., Décoppet, J.-D., Zakeeruddin, S.M., Grätzel, M. and Yeh, C.-Y. (2015) Porphyrin Sensitizers Bearing a Pyridine-Type Anchoring Group for Dye-Sensitized Solar Cells. ACS Applied Materials \& Interfaces, 7, 14975 14982. https://doi.org/10.1021/acsami.5b03783

[26] Mathew, S., Yella, A., Gao, P., Humphry-Baker, R., Curchod, B.F.E., Ashari-Astani, N., Tavernelli, I., Rothlisberger, U., Nazeeruddin, M.K. and Grätzel, M. (2014) DyeSensitized Solar Cells with 13\% Efficiency Achieved through the Molecular Engineering of Porphyrin Sensitizers. Nature Chemistry. 6, 242-247. https://doi.org/10.1038/nchem.1861

[27] Armarego, W.L. and Chai, C. (2009) Purification of Laboratory Chemicals. 6th Edition, Butterworth-Heinemann, Elsevier, UK.

[28] Mamardashvili, N.Zh. and Golubchikov, O.A. (2001) Spectral Properties of Porphy- 
rins and Their Precursors and Derivatives. Russian Chemical Reviews, 70, 577-606. https://doi.org/10.1070/RC2001v070n07ABEH000661

[29] Walker, F.A., Balke, V.L. and McDermott, G.A. (1982) Electronic Effects in Transition-Metal Porphyrins. 4. Effect of Unsymmetrical Phenyl Substitution on the NMR Spectra of a Series of Metal-Free and Zinc Tetraphenylporphyrins. Inorganic. Chemistry, 21, 3342-3348.

[30] Kevin, M., Smith, K.M., Abraham, R.J. and Pearson, H. (1982) The NMR Spectra of Porphyrins-19. Tetrahedron, 38, 2441-2449.

[31] Drouet, S., Merhi, A., Argouarch, G., Paul, F., Mongin, O., Blanchard-Desce, M. and Paul-Roth, C.O. (2012) Synthesis of New Luminescent Supramolecular Assemblies from Fluorenyl Porphyrins and Polypyridyl Isocyanurate-Based Spacers. Tetrahedron, 68, 98-105.

[32] Gouterman, M. (1961) Spectra of Porphyrins. Journal of Molecular Spectroscopy, 6, 138-163.

[33] Spellane, P.J., Gouterman, M., Antipas, A., Kim, S. and Liu, Y.C. (1980) Porphyrins. 40. Electronic Spectra and Four-Orbital Energies of Free-Base, Zinc, Copper, and Palladium Tetrakis(Perfluorophenyl)Porphyrins. Inorganic Chemistry, 19, 386-391. https://doi.org/10.1021/ic50204a021

[34] Gouterman, M. (1979) The Porphyrins. Vol. III, Academic Press, New York.

[35] Liu, W., Shi, Y.-H., Wang, Y.-J., Shi, T.-S. and Zhang, W.-J. (2003) Synthesis of Tetra(4-n-Lauryloyloxyphenyl)Porphyrin Complexes and Its Liquid Crystalline Characterization. Chemical Journal of Chinese Universities, 24, 200-204.

[36] Michaelian, K.H., Wen, Q., Billinghurst, B.E., Shaw, J.M. and Lastovka, V. (2012) Far- and Mid-Infrared Photoacoustic Spectra of Tetracene, Pentacene, Perylene and Pyrene. Vibrational Spectroscopy, 58, 50-56.

[37] Boersma, C., Mattioda, A.L., Bauschlicher Jr., C.W., Peeters, E., Tielens, A.G.G.M. and Allamandola, L.J. (2009) The 5.25 and $5.7 \mu \mathrm{m}$ Astronomical Polycyclic Aromatic Hydrocarbon Emission Features. The Astrophysical Journal, 690, 1208. https://doi.org/10.1088/0004-637X/690/2/1208

[38] Joblin, C., d'Hendecourt, L., Léger, A. and Défourneau, D. (1994) Infrared Spectroscopy of Gas-Phase PAH Molecules. Astronomy and Astrophysics, 281, 923-936.

[39] Szczepanski, J. and Vala, M. (1993) Infrared Frequencies and Intensities for Astrophysically Important Polycyclic Aromatic Hydrocarbon Cations. Astrophysical Journal, 414, 646-655. https://doi.org/10.1086/173110

[40] Gritzner, G. and Kuta, J. (1984) Recommendations on Reporting Electrode Potentials in Nonaqueous Solvents. Pure \& Applied Chemistry, 56, 461-466. https://doi.org/10.1351/pac198456040461

[41] Rault-Berthelot, J., Paul-Roth, C., Poriel, C., Juillard, S., Ballut, S., Drouet, S. and Simonneaux, G. (2008) Comparative Behaviour of the Anodic Oxidation of Mono-, Di- and Tetra-Arylporphyrins: Towards New Electroactive Materials with Variable Bandgaps. Journal of Electroanalytical Chemistry, 623, 204-214.

[42] Felton, R.H. and Linschitz, H. (1966) Polarographic Reduction of Porphyrins and Electron Spin Resonance of Porphyrin Anions. Journal of the American Chemical Society, 88, 1113-1116. https://doi.org/10.1021/ja00958a004

[43] Kadish, K.M., Sazou, D., Liu, Y.M., Saoiabi, A., Ferhat, M. and Guilard, R. (1988) Electrochemical and Spectral Characterization of the Monomer-Dimer Equilibrium Involving (Meso-tetrakis(1-methylpyridinium-4-yl)porphinato)nickel(II) in Dimethylformamide. Inorganic Chemistry, 27, 686-690.

https://doi.org/10.1021/ic00277a023 
[44] Engelmann, F.M., Losco, P., Winnischofer, H., Araki, K. and Toma, H.E. (2002) Synthesis, Electrochemistry, Spectroscopy and Photophysical Properties of a Series of Meso-Phenylpyridylporphyrins with One to Four Pyridyl Rings Coordinated to $\left[\mathrm{Ru}(\text { bipy })_{2} \mathrm{Cl}\right]^{+}$Groups. Journal of Porphyrins and Phthalocyanines, 6, 33-42. https://doi.org/10.1142/S1088424602000063

[45] Paul-Roth, C.O. and Simonneaux, G. (2006) Porphyrins with Fluorenyl and Fluorenone Pendant arms. Tetrahedron Letters, 47, 3275-3278.

[46] Paul-Roth, C., Rault-Berthelot, J., Simonneaux, G., Letessier, J. and Bergamini, J.-F. (2007) Selective Anodic Preparation of 1D or 2D Electroactive Deposits from 5, 15-Bis-(9H-fluoren-2-yl)-10,20-Diphenyl Porphyrins. Journal of Electroanalytical Chemistry, 606, 103-116.

[47] Paul-Roth, C.O. and Simonneaux, G. (2006) Porphyrins with Fluorenyl and Fluorenone Pendant Arms as Red-Light-Emitting Devices. Comptes Rendus Chimie, 9, 1277-1286.

[48] Reed, R.A., Purrello, R., Prendergast, K. and Spiro, T.G. (1991) Resonance Raman Characterization of the Radical Anion and Triplet States of Zinc Tetraphenylporphine. The Journal of Physical Chemistry, 95, 9720-9727. https://doi.org/10.1021/j100177a024

[49] Li, B., Li, J., Fu, Y. and Bo, Z. (2004) Porphyrins with Four Monodisperse Oligofluorene Arms as Efficient Red Light-Emitting Materials. Journal of the American Chemical Society, 126, 3430-3431. https://doi.org/10.1021/ja039832y

[50] Lever, A.B.P. (1990) Electrochemical Parametrization of Metal Complex Redox Potentials, Using the Ruthenium(III)/Ruthenium(II) Couple to Generate a Ligand Electrochemical Series. Inorganic Chemistry, 29, 1271-1285.

https://doi.org/10.1021/ic00331a030

Submit or recommend next manuscript to SCIRP and we will provide best service for you:

Accepting pre-submission inquiries through Email, Facebook, LinkedIn, Twitter, etc. A wide selection of journals (inclusive of 9 subjects, more than 200 journals)

Providing 24-hour high-quality service

User-friendly online submission system

Fair and swift peer-review system

Efficient typesetting and proofreading procedure

Display of the result of downloads and visits, as well as the number of cited articles

Maximum dissemination of your research work

Submit your manuscript at: http://papersubmission.scirp.org/

Or contact ampc@scirp.org 